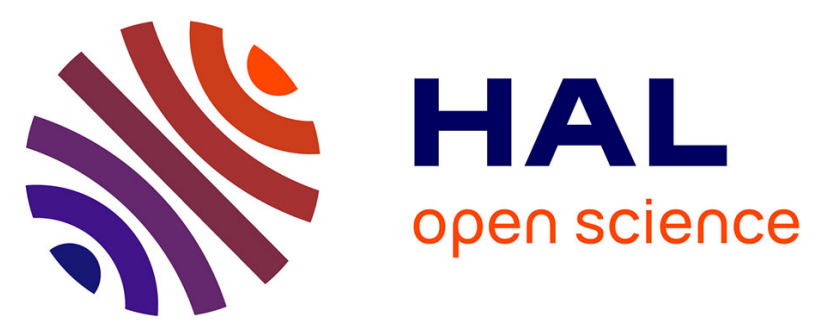

\title{
Absence of cumulus cells during in vitro maturation affects lipid metabolism in bovine oocytes
}

Sylvain Auclair, Rustem Uzbekov, Sébastien Elis, Laura Sanchez, Igor Kireev, Lionel Lardic, Rozenn Dalbies-Tran, Svetlana Uzbekova

\section{- To cite this version:}

Sylvain Auclair, Rustem Uzbekov, Sébastien Elis, Laura Sanchez, Igor Kireev, et al.. Absence of cumulus cells during in vitro maturation affects lipid metabolism in bovine oocytes. AJP - Endocrinology and Metabolism, 2013, 304 (6), pp.E599-E613. 10.1152/ajpendo.00469.2012 . hal-01129721

\section{HAL Id: hal-01129721 \\ https://hal.science/hal-01129721}

Submitted on 29 May 2020

HAL is a multi-disciplinary open access archive for the deposit and dissemination of scientific research documents, whether they are published or not. The documents may come from teaching and research institutions in France or abroad, or from public or private research centers.
L'archive ouverte pluridisciplinaire HAL, est destinée au dépôt et à la diffusion de documents scientifiques de niveau recherche, publiés ou non, émanant des établissements d'enseignement et de recherche français ou étrangers, des laboratoires publics ou privés. 


\section{Absence of cumulus cells during in vitro maturation affects lipid metabolism in bovine oocytes Sylvain Auclair, Rustem Uzbekov, Sébastien Elis, Laura Sanchez, Igor Kireev, Lionel Lardic, Rozenn Dalbies-Tran and Svetlana Uzbekova \\ Am J Physiol Endocrinol Metab 304:E599-E613, 2013. First published 15 January 2013; doi: 10.1152/ajpendo.00469.2012}

You might find this additional info useful...

This article cites 81 articles, 34 of which you can access for free at:

http://ajpendo.physiology.org/content/304/6/E599.full\#ref-list-1

Updated information and services including high resolution figures, can be found at: http://ajpendo.physiology.org/content/304/6/E599.full

Additional material and information about American Journal of Physiology - Endocrinology and

Metabolism can be found at:

http://www.the-aps.org/publications/ajpendo

This information is current as of July 17, 2013.

American Journal of Physiology - Endocrinology and Metabolism publishes results of original studies about endocrine and metabolic systems on any level of organization. It is published 24 times a year (twice monthly) by the American Physiological Society, 9650 Rockville Pike, Bethesda MD 20814-3991. Copyright @ 2013 the American Physiological Society. ESSN: 1522-1555. Visit our website at http://www.the-aps.org/. 


\title{
Absence of cumulus cells during in vitro maturation affects lipid metabolism
}

\section{in bovine oocytes}

\author{
Sylvain Auclair, ${ }^{\text {a,b,c,d }}$ Rustem Uzbekov, ${ }^{\text {e,f }}$ Sébastien Eliss, ${ }^{\text {a,b,c,d }}$ Laura Sanchez, ${ }^{\text {a,b,c,d }}{ }^{\text {Igor Kireev, }}$, \\ Lionel Lardic, a,b,c,d Rozenn Dalbies-Tran, ${ }^{\text {a,d,c,d }}$ and Svetlana Uzbekova ${ }^{\text {a,b,c,d }}$ \\ ${ }^{a}$ UMR85 Physiologie de la Reproduction et des Comportements, Institut National de la Recherche Agronomique, Nouzilly,

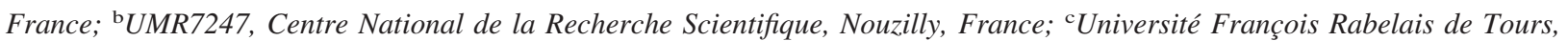 \\ Tours, France; ${ }^{\mathrm{d} I n s t i t u t ~ F r a n c ̧ a i s ~ d u ~ C h e v a l ~ e t ~ d e ~ l ' E q u i t a t i o n, ~ N o u z i l l y, ~ F r a n c e ; ~}{ }^{\mathrm{e}}$ Laboratoire Biologie Cellulaire et \\ Microscopie Electronique, Faculté de Médecine, Université François Rabelais, Tours, France; ${ }_{\mathrm{f}}^{\mathrm{f}}$ Faculty of Bioengineering and \\ Bioinformatics, Moscow State University, Moscow, Russia; and ${ }^{\mathrm{g}}$ Department of Electron Microscopy A.N.Belozersky Institute \\ of Physico-Chemical Biology, Moscow State University, Moscow, Russia
}

Submitted 18 September 2012; accepted in final form 4 January 2013

Auclair S, Uzbekov R, Elis S, Sanchez L, Kireev I, Lardic L, Dalbies-Tran R, Uzbekova S. Absence of cumulus cells during in vitro maturation affects lipid metabolism in bovine oocytes. Am J Physiol Endocrinol Metab 67: E599-E613, 2013. First published January 15, 2013; doi:10.1152/ajpendo.00469.2012._Cumulus cells (CC) surround the oocyte and are coupled metabolically through regulation of nutrient intake. $\mathrm{CC}$ removal before in vitro maturation (IVM) decreases bovine oocyte developmental competence without affecting nuclear meiotic maturation. The objective was to investigate the influence of $\mathrm{CC}$ on oocyte cytoplasmic maturation in relation to energy metabolism. IVM with either cumulus-enclosed (CEO) or -denuded (DO) oocytes was performed in serum-free metabolically optimized medium. Transmission electron microscopy revealed different distribution of membrane-bound vesicles and lipid droplets between metaphase II DO and CEO. By Nile Red staining, a significant reduction in total lipid level was evidenced in DO. Global transcriptomic analysis revealed differential expression of genes regulating energy metabolism, transcription, and translation between CEO and DO. By Western blot, fatty acid synthase (FAS) and hormone-sensitive phospholipase (HSL) proteins were detected in oocytes and in CC, indicating a local lipogenesis and lypolysis. FAS protein was significantly less abundant in DO that in CEO and more highly expressed in $\mathrm{CC}$ than in the oocytes. On the contrary, HSL protein was more abundant in oocytes than in CC. In addition, active $\mathrm{Ser}^{563}$-phosphorylated HSL was detected in the oocytes only after IVM, and its level was similar in CEO and DO. In conclusion, absence of CC during IVM affected lipid metabolism in the oocyte and led to suboptimal cytoplasmic maturation. Thus, CC may influence the oocyte by orienting the consumption of nutritive storage via regulation of local fatty acid synthesis and lipolysis to provide energy for maturation.

bovine oocyte; cumulus cells; in vitro maturation; ultrastructure; lipid metabolism

IN THE GROWING FOLLICLES, the mammalian oocyte is enclosed with somatic cells and sequentially acquires the capacities leading to the success of fertilization, embryo development, and offspring $(49,65)$. Follicular environment and bidirectional dialog between somatic and germinal cells allow the oocyte to acquire its meiotic and developmental competence during folliculogenesis $(6,7)$ and subsequent maturation of the oocyte, preparing it to ovulate and to accept spermatozoa.

Address for reprint requests and other correspondence: S.Uzbekova, INRA UMR85 Physiologie de la Reproduction et des Comportements, 37380 Nouzilly France (e-mail: svetlana.uzbekova@tours.inra.fr).
Oocyte maturation is viewed at nuclear, cytoplasm, and molecular levels (for review, see Ref. 63). RNA, protein, and nutrition stockpiles are accumulated in the oocyte before ovulation and expected to support embryo development through several cleavages before major embryo genome activation occurring at 4/8-cell transition in human and 8/16-cell in bovine (74). In antral follicles, specialized granulosa cells surrounding the oocyte, named cumulus cells (CC), are involved in the acquisition of oocyte developmental competence. These cells are physically and metabolically coupled with an oocyte during its growth and maturation and also participate in ovulation and fertilization $(26,71)$. Indeed, during antral follicle growth, $\mathrm{CC}$ are in tight relation with the oocyte through gap junctions that allows a bidirectional paracrine signaling $(36,38)$, thus regulating different processes, including chromatin remodeling and RNA synthesis in the oocyte (45). CC are particularly involved in antioxidative and metabolic processes, such as reducing cystin to cystein and metabolizing glucose to pyruvate, respectively; these components are provided to the oocytes by $\mathrm{CC}$ and known to improve oocyte quality $(70,71,73)$. Glucose is the main energy source for the oocyte, and therefore glucose metabolism is crucial for oocyte maturation and early embryo development (70). However, because of the low capacity of the oocytes to utilize glucose, this substrate is mainly metabolized by $\mathrm{CC}$ via different pathways, including glycolysis and the pentose phosphate pathway to provide an oocyte with pyruvate for energy production $(55$, 67). CC are involved in providing energy substrates as fatty acids (FA), carbohydrates, and amino acids from surrounding fluids to the oocyte. The oocyte also contributes to $\mathrm{CC}$ functioning through the secretion of different oocyte-specific factors and thus regulates its own microenvironment to acquire a better capacity to develop into an embryo (25). Environmental conditions of oocyte maturation have a strong impact on embryo developmental capacity (64). Gene expression patterns in the oocyte $(33,44)$ and in $C C(5,22)$ during maturation are associated with its developmental potential in bovine and human species in vitro and in vivo. Several global transcriptomic studies were carried out in cattle to identify molecular markers or signatures of oocytes associated with developmental competence by comparing gene expression patterns before and after in vitro maturation (IVM) $(20,47,76)$ as well as in vitro vs. in vivo matured oocytes (35).

The importance of CC during IVM of bovine oocytes was highlighted in the studies comparing developmental potential 
of the oocytes matured in vitro with or without CC. In fact, cumulus-denuded oocytes (DO) could be fertilized only when coincubated with intact cumulus-enclosed oocytes (CEO) during in vitro fertilization (IVF), although, even in such condition, zygotes obtained from DO showed significantly lower developmental rate compared with CEO in bovine (46). However, coincubation of DO with CEO during IVM partially restored their capacity to develop $(14,46)$. Differences in developmental competence of DO and CEO are linked to several factors, including cAMP and glutathione content in the oocyte (46). In bovine oocytes, meiosis resumption is associated with a decrease in AMP-activated protein kinase (AMPK) activity both in the oocyte and surrounding CC (78). AMPK is considered as a key regulator of glucose and lipid metabolism (34). We showed previously that IVM in the presence of AMPK activator metformin led to meiotic arrest of CEO but not DO in bovine (78). Recent transcriptomic study reported that a number of genes involved in cellular metabolism were differently expressed between bovine CEO and DO after IVM in medium complemented with serum (56). All these findings support the hypothesis that $\mathrm{CC}$ are strongly involved in proper regulation of the oocyte metabolism during IVM.

The aim of the present work was to investigate the consequences of CC removal before IVM on oocyte maturation in relation with its energy metabolism factors, which may correlate with oocyte development competence. Toward these perspectives, it appears important to gain a better knowledge concerning CC participation in oocyte energy metabolism regulation. We bring complementary information to previous studies, since here we used defined serum and FA-free metabolically optimized medium TCM199EM containing an equilibrated quantity of pyruvate, glutathione, and amino acids and enriched in gonadotropins and growth factors, which was reported to be very efficient for IVM of bovine oocytes in terms of developmental potential $(15,57)$. An original integrative comparative approach, including analysis of oocyte ultrastructure, transcriptome, lipid content, and associated proteins, was employed to enlighten the cytoplasmic and molecular aspects of oocyte maturation. Beyond the fundamental interest, this information is of importance in the context of reproductive technologies. IVM of human oocytes after morphological observation as DO may be useful in human reproductive technology protocols. Moreover, IVM and further fertilization of DO is helpful for functional studies when using microinjections in immature oocytes in mammalian species.

\section{MATERIALS AND METHODS}

\section{Ethics}

All procedures were approved by the Agricultural and Scientific Research Government Committees in accordance with the guidelines for Care and Use of Agricultural Animals in Agricultural Research and Teaching (approval A37801).

\section{Materials}

All substances where the name of a commercial supplier is not stated were purchased from Sigma (Saint Quentin Fallavier, France).

\section{Samples}

Oocyte collection and IVM. Bovine ovaries were collected from a slaughterhouse; 3- to 8- $\mathrm{mm}$ antral follicles from 40-50 ovaries/ experiment were aspirated and pooled. Cumulus-oocyte complexes (COC) with several compact layers of CC were selected and washed several times in TCM199/HEPES medium supplemented with $50 \mathrm{mg} / \mathrm{l}$ gentamycin and $0.1 \%$ BSA. One-half of oocytes was stripped off CC by repetitive aspirating-ejecting movements using a P100 Gilson pipette with a tip in several successive 100- $\mu$ l drops under observation with a stereomicroscope. Completely naked morphologically undamaged oocytes were removed from the drops and washed from residual CC two times in a Petri dish containing $3 \mathrm{ml}$ of TCM199 medium. Next, groups of either $50 \mathrm{CEO}$ or DO were subjected to IVM at $38.8^{\circ} \mathrm{C}$ for $22 \mathrm{~h}$ in a humidified atmosphere containing $5 \% \mathrm{CO}_{2}$ in 500 $\mu l$ of TCM199-enriched medium containing recombinant human (rh) epidermal growth factor (EGF, $10 \mathrm{ng} / \mathrm{ml}$ ), rh insulin-like growth factor-I (IGF-I, $19 \mathrm{ng} / \mathrm{ml}$ ), rh basic fibrobalst growth factor (2.2 $\mathrm{ng} / \mathrm{ml}$ ), human chorionic gonadotropin (hCG, $5 \mathrm{IU} / \mathrm{ml}$; Intervet, Beaucouze, France), pregnant mare serum gonadotropin (PMSG, $10 \mathrm{IU} / \mathrm{ml}$; Intervet), rh insulin $(5 \mu \mathrm{g} / \mathrm{ml})$, rh transferrin $(5 \mu \mathrm{g} / \mathrm{ml})$, sodium selenite $(5 \mathrm{ng} / \mathrm{ml})$, L-cystein $(90 \mu \mathrm{g} / \mathrm{ml}), \beta$-mercaptoethanol $(0.1$ $\mathrm{mM})$, ascorbic acid $(75 \mu \mathrm{g} / \mathrm{ml})$, glycine $(720 \mu \mathrm{g} / \mathrm{ml})$, glutamine $(0.1$ $\mathrm{mg} / \mathrm{ml})$, and pyruvate $(110 \mu \mathrm{g} / \mathrm{ml})$ as described (15). At the end of maturation, CEO were stripped off $\mathrm{CC}$, and oocytes from both $\mathrm{CEO}$ and DO groups were collected and then kept frozen at $-80^{\circ} \mathrm{C}$ until RNA or protein extraction. Immature naked oocytes (IO) were also collected before IVM. Meiotic status of oocytes was established by chromatin labeling with Hoechst 33342 (1 $\mu \mathrm{g} / \mathrm{ml})$, followed by microscopic observation. At least 100 mature oocytes were analyzed for their nuclear status in each experimental situation (CEO and DO). In total, three groups of naked oocytes were analyzed as follows: 1) $\mathrm{CEO}$, oocytes matured enclosed in intact COCs and denuded after IVM; 2) DO, oocytes denuded from the compact COCs before IVM and so matured; and 3) IO, immature oocytes denuded from the compact COCs before IVM.

$I V F$. After $22 \mathrm{~h}$ of IVM, CEO and DO were washed in fertilization medium (Tyrode medium with $25 \mathrm{mM}$ bicarbonate, $10 \mathrm{mM}$ lactate, 1 $\mathrm{mM}$ pyruvate, $6 \mathrm{mg} / \mathrm{ml}$ fatty acid-free BSA, $100 \mu \mathrm{g} / \mathrm{ml}$ heparin, and $40 \mu \mathrm{g} / \mathrm{ml}$ gentamycin) and transferred into four-well dishes (25 CEO + 25 DO in $250 \mu \mathrm{l}$ fertilization medium/well). Motile spermatozoa, obtained by centrifugation of frozen/thawed semen on a discontinuous Percoll (Pharmacia, Uppsala, Sweden) density gradient (45/90\%), were diluted in fertilization medium $\left(2 \times 10^{6}\right.$ spermatozoa $\left./ \mathrm{ml}\right)$. Oocytes and spermatozoa $(250 \mu \mathrm{l}$ of the previous suspension/well) were incubated together for $18 \mathrm{~h}$ at $38.8^{\circ} \mathrm{C}$ in a humidified atmosphere with $5 \% \mathrm{CO}_{2}$ in $95 \%$ air. At the end of the fertilization period, CEO and DO were separated; presumptive zygotes were mechanically denuded and washed in 199H/BSA medium.

In vitro development. Presumptive zygotes after IVF were washed three times in modified synthetic oviduct fluid (mSOF) (28) with $5 \%$ FBS (MP Biomedicals, Illkirch, France) and then cultured in a microdrop of mSOF with 5\% FBS (20-25 embryos/25 $\mu \mathrm{l})$ under paraffin oil at $38.8^{\circ} \mathrm{C}$ for 8 days in a water-saturated atmosphere of $5 \%$ $\mathrm{CO}_{2}-5 \% \mathrm{O}_{2}-90 \% \mathrm{~N}_{2}$. Embryonic cleavage rate (ratio of the number of cleaved zygotes to the total number of the oocytes subjected to IVF) and blastocyst rate (ratio of the number of blastocysts to the number of cleaved embryos) were determined $48 \mathrm{~h}$ and 8 days after IVF, respectively. The rate of hatched blastocysts (no. of hatched blastocysts/total blastocyst no.) was recorded at day 8 post-IVF. In total, developmental rates of $577 \mathrm{CEO}$ and $566 \mathrm{DO}$ were checked in four independent IVF experiments. Cleavage, blastocyst, and hatching rates were compared between CEO and DO groups (4 replicates/ group) by using the $\chi^{2}$-test and nonparametric Mann Whitney test.

Microphotographs of 8-day blastocysts were obtained by using camera 11.2 Color Mosaic and Spot Advanced 4.0.1 software (Diagnostic Instruments). The diameter of the blastocyst derived from CEO $(n=39)$ and DO $(n=16)$ was measured by using Visilog software (Neosis, Gif sur Yvette, France) and compared by using $t$-test. 


\section{RNA Analysis}

RNA extraction and amplification. Mature oocytes from both CEO and DO groups after IVM were selected on the criteria of the presence of polar body. Luciferase (luc, $250 \mathrm{pg}$ ) as an external standard was added to each pool of 25 oocytes (10 pg of luc/oocyte; CEO and DO) (Promega, Charbonnières-les-bains, France), and total DNase-treated RNA was extracted using a Picopure RNA isolation kit (Alphelys, Plaisir, France) according to the manufacturer's instructions. Total RNA was subsequently amplified using a RiboAmp Plus kit (Alphelys) following the manufacturer's instructions, and aRNA produced was validated using the Bioanalyzer 2100 RNA 6000 nanochip (Agilent Technologies).

$R T$-PCR. RNA from 25 oocytes was converted in $25 \mu l$ of cDNA using oligo $(\mathrm{dT})_{15}$ primers $(0.25 \mu \mathrm{g} /$ reaction $)$ and mouse Moloney leukemia virus reverse transcriptase (Invitrogen) for $1 \mathrm{~h}$ at $37^{\circ} \mathrm{C}$ $(\mathrm{cDNA}$ concentration $=1$ oocyte equivalent $/ \mu \mathrm{l})$. To validate the primers, PCR was performed using SYBR Green supermix (Bio-Rad, Marnes la Coquette, France) and specific primers (Table 1) from 1\% of obtained cDNA as a template for each gene. PCR products were visualized by migration on $1.5 \%$ agarose gel.

Real-time RT-PCR. Real-time PCR was performed on a MyiQ Cycler apparatus (Bio-Rad). Reactions were performed in a total volume of $20 \mu \mathrm{l}$ using SYBR green Bio-Rad supermix and $0.3 \mu \mathrm{M}$ of each specific primer in triplicate for each sample. Routinely, cDNA was diluted 100 times $(\mathrm{cDNA}$ concentration $=0.01$ oocyte equivalent $/ \mu 1)$. For one PCR reaction, 5 or $10 \mu \mathrm{l}$ of this dilution were used ( 0.05 or 0.1 oocyte equivalents). A three-step protocol $\left(95^{\circ} \mathrm{C}\right.$ for $30 \mathrm{~s}$, $60^{\circ} \mathrm{C}$ for $30 \mathrm{~s}, 72^{\circ} \mathrm{C}$ for $20 \mathrm{~s}$ ) was repeated for 40 cycles, followed by acquisition of the melting curve. The standard curve for each gene was deduced from serial dilutions of the correspondent cDNA fragment. Correlation coefficients and PCR efficiencies were $>0.99$ and $92 \%$, respectively.

The relative level of mRNA expression was calculated in at least four independent oocyte samples for each condition as follows. The median value from technical triplicates was considered for each sample and then it was normalized to the correspondent median value of external luc mRNA and to serine-threonine aurora kinase A (AURKA), considered as the internal reference gene since its level does not change during IVM in bovine oocytes (75). Values of relative mRNA levels (ratio gene of interest/geometric mean luc and AURKA) were compared using nonparametric Mann Whitney test (GraphPad Prism, San Diego, CA); the difference was considered significant at a $P$ value $<0.05$.

\section{Microarray Hybridization}

aRNA labeling and hybridization. Two micrograms of each sample were labeled using the ULS aRNA labeling kit (Kreatech, Amsterdam, Netherlands) according to the manufacturer's instructions. The dye swap approach was used by labeling CEO and DO alternatively by cyanine 3 and 5 . Subsequently, $50 \mathrm{pmol}$ of each condition (CEO and DO) were then fragmented for $15 \mathrm{~min}$ at $70^{\circ} \mathrm{C}$ using the RNA Fragmentation Reagents (Ambion, Austin, TX) and then stopped with Stop solution. Hybridization was achieved using bovine $22 \mathrm{~K}$ arrays obtained from CRB GADIE (INRA, Jouy en Josas, France) and SlideBooster apparatus (Advalytix; Beckman Coulter Biomedical). Briefly, a presoak step was performed for $30 \mathrm{~min}$ at $42^{\circ} \mathrm{C}$ using the Pronto Background Reduction Kit (Corning) and then washed tree times with water. Next, the slides were dynamically hybridized for $\sim 16 \mathrm{~h}$ at $42^{\circ} \mathrm{C}$ using the SlideBooster system in $60 \mu \mathrm{l}$ of Advahyb buffer (Advalytix; Beckman Coulter Biomedical). Finally, slides were washed using AdvaWash apparatus and buffers (Advalytix; Beckman Coulter Biomedical).

Microarray data acquisition, statistics, and gene ontology analysis. Slides were scanned at both dye channels (532 $\mathrm{nm}$ for cyanine 3, 635 nm for cyanine 5) with a GenePix 4000B scanner, and data acquisition was performed using GenePix Pro 6.0 (Axon Molecular Devices, Sunnyvale, CA).

For this experiment, gene expression analysis was carried out between CEO and DO, representing a total of eight slides (dye swap protocol), and differentially expressed genes were identified using the Anapuce package of R software (29). For each spot, median intensity values were $\log 2$ transformed before a normalization step that consisted of a global locally weighted regression (Lowess) to compensate dye bias between the two cyanines. Next, a block effect was adjusted by subtracting from each block the median intensity. Data were deposited in the public repository Gene Expression Omnibus with the following series entry: GSE31361.

\section{Statistics}

Data were analyzed with a mixture model variance [VarMixt method (13)] and a standard Student's $t$-test to detect differentially expressed genes; probability values were adjusted using the Benjamini and Hochberg correction at 5\% to limit false positives (18).

Table 1. Oligonucleotide primer sequences used for real-time RT-PCR

\begin{tabular}{|c|c|c|c|c|}
\hline Gene & Primer & Sequence $\left(5^{\prime}-3^{\prime}\right)$ & Accession No. & Amplicon Size, bp \\
\hline \multirow[t]{2}{*}{ AURKA } & Forward & TCGGGAGGACTTGGTTTCTT & DQ334808 & 234 \\
\hline & Reverse & TGTGCTTGTGAAGGAACACG & & \\
\hline \multirow[t]{2}{*}{ FASN } & Forward & CACTCCATCCTCGCTCTCC & AY343889 & 181 \\
\hline & Reverse & GCCTGTCATCATCTGTCACC & & \\
\hline \multirow[t]{2}{*}{ LIPE } & Forward & GAGTTTGAGCGGATCATTCA & NM_001080220 & 102 \\
\hline & Reverse & TGAGGCCATGTTTGCTAGAG & & \\
\hline \multirow[t]{2}{*}{ LEO1 } & Forward & AGCAGCGCCGCATGAGAG & BC120399 & 95 \\
\hline & Reverse & TCACCCTCCTTCCTCCTCCTC & & \\
\hline \multirow[t]{2}{*}{ Luc } & Forward & TCATTCTTCGCCAAAAGCACTCTG & AB644228 & 149 \\
\hline & Reverse & AGCCCATATCCTTGTCGTATCCC & & \\
\hline \multirow[t]{2}{*}{ MED10 } & Forward & CCCGCGCTGACAGTTTTCTTG & BC102439 & 169 \\
\hline & Reverse & ACGCATTCTTTATGCACCACACTC & & \\
\hline \multirow[t]{2}{*}{ RPS20 } & Forward & CCACAAGCGACTCATTGACCTG & BC103289 & 106 \\
\hline & Reverse & GGCATCAGCAATGGTGACTTCC & & \\
\hline \multirow[t]{2}{*}{ RPS9 } & Forward & GGAGACCCTTCGAGAAGTCC & BC148016 & 180 \\
\hline & Reverse & GGGCATTACCTTCGAACAGA & & \\
\hline
\end{tabular}

AURKA, serine-threonine kinase aurora A; LEO1, Paf1/RNA polymerase II complex component; luc, firefly luciferase, external control RNA; MED10,

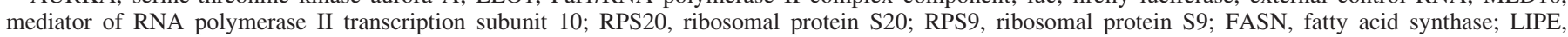
hormone-sensitive lipase. 


\section{Gene Ontology}

Differentially expressed genes were classified according to their biological and molecular functions using the online Database for Annotation, Visualization and Integrative Discovery (DAVID) tools (29) (http://david.abcc.ncifcrf.gov/). Significantly enriched annotation terms and pathways were identified in a differentially expressed gene set compared with the total gene list using the DAVID web service, which employs a Fischer exact test with corrected $P$ value cutoff of 0.05 .

\section{Protein Analysis}

Antibodies. Mouse monoclonal antibodies to rh proteins RPS17 (clone 2C7), $\alpha$-tubulin (TUBA, clone DM1), and rabbit polyclonal antibodies to rh RPS20 were purchased from Sigma (Saint Quentin). Rabbit polyclonal antibodies to synthetic phosphopeptide corresponding to residues surrounding $\mathrm{Thr}^{202} / \mathrm{Tyr}^{204}$ and $\mathrm{Thr}^{185 / 187}$ of human mitogen-activated protein kinase (MAPK) 3 and MAPK1, to phospho$\mathrm{Ser}^{563}$ of human hormone-sensitive lipase (HSL), to synthetic peptide of human HSL, and rabbit monoclonal antibodies to synthetic peptide within human fatty acid synthase (FAS, clone C20G5) were purchased from Cell Signaling Technology (Ozyme, Saint Quentin Yvelines, France). Rabbit polyclonal antibodies to rat ERK2 (MAPK1, C14) were from Santa Cruz Biotechnology (Santa Cruz, CA). Polyclonal goat antibodies against human MED10 and mouse polyclonal antibodies to synthetic peptide of human LEO1 were provided by Abcam (Cambridge, UK).

Horseradish peroxidase (HRP)-conjugated goat anti-rabbit and donkey anti-goat antibodies were purchased from Cell Signaling Technology; HRP-conjugated goat anti-mouse IgG was from Lab Vision (Fremont, CA).

\section{Western Immunoblotting}

Groups of 50 oocytes were lysed in Tris-saline-EGTA buffer $(\mathrm{pH}$ 7.5) supplemented with $2 \mathrm{mM}$ sodium orthovanadate and $1 \mu \mathrm{l} / \mathrm{ml}$ of protease inhibitor cocktail (Sigma) and then freeze-thawed three times by rapid incubation in liquid nitrogen followed by immersion in a warm water bath at $30^{\circ} \mathrm{C}$. Before loading, concentrated reducing Laemmli buffer, containing $80 \mathrm{mM}$ dithiothreitol at a final concentration was added to all protein extracts, and samples were boiled for $8 \mathrm{~min}$ and then centrifuged $5 \mathrm{~min}$ at $12,000 \mathrm{~g}$.

Protein extracts were resolved on 10-15\% SDS-PAGE and transferred on nitrocellulose membranes. Blots were blocked with $5 \%$ of milk powder in Tris-buffered saline/ $0.1 \%$ Tween 20 for $1 \mathrm{~h}$ at room temperature and probed with the various antibodies overnight at $4{ }^{\circ} \mathrm{C}$. Dilutions were 1:50 for MED10, RPS17, and RPS20; 1:500 for pSer ${ }^{563}$-HSL, HSL, and FAS; and 1:1,000 for vinculin, TUBA, LEO1, phospho-MAPK3/1, and MAPK1 primary antibodies. After washing, immunoreactivity was detected using the appropriate HRP-conjugated secondary antibodies (diluted 1:5,000, incubated $1 \mathrm{~h}$ at room temperature) and revealed by an enhanced chemiluminescence ECL Plus kit (Amersham Biosciences, Orsay, France). Densitometry was performed by scanning the original radiographs and then analyzing the bands with Scion Image for Windows (Scion). At least three independent samples were analyzed for each experimental condition. The data are expressed as a ratio of signal intensities in arbitrary units of protein of interest to TUBA protein. Normalized data have been subjected to the nonparametric Mann Whitney test; difference was considered significant at a $P$ value $<0.05$.

\section{Electron Microscopy Analysis of Oocyte Ultrastructure}

Oocytes from each group (IO, IVM CEO, and IVM DO) completely denuded from their CC were fixed for $48 \mathrm{~h}$ in $4 \%$ paraformaldehyde/1\% glutaraldehyde/ $0.1 \mathrm{M}$ phosphate buffer $\mathrm{pH} 7.2$ [Electron Microscopy Science (EMS)] and then postfixed by incubation for $1 \mathrm{~h}$ with $1 \%$ osmium tetroxide (EMS). Samples were dehydrated in graded ethanol and propylene oxide baths, embedded in Epon resin (Fluka), and incubated at $60^{\circ} \mathrm{C}$ for $48 \mathrm{~h}$. Serial semithin $(1 \mu \mathrm{m})$ and ultrathin $(70 \mathrm{~nm})$ sections were cut using an Ultracut UCT ultramicrotome (Leica).

In total, $10 \mathrm{IO}, 8 \mathrm{CEO}$, and $7 \mathrm{DO}$ were analyzed. Semithin sections were colored by toluidine blue (Merck) and examined with an Olympus FluoView 500 (Japan) confocal microscope (laser HeNe $544 \mathrm{~nm}$ ). Microphotographs of semithin sections were obtained by using camera 11.2 Color Mosaic and Spot Advanced 4.0.1 software. The total area of midequatorial sections of each oocyte $(n=25)$ and the number and areas of gray lipid droplets (LDs) and white vesicles were measured using ImageJ 1.45o software (61). The LDs and vesicle area fractions were compared between IO, CEO, and DO using ANOVA followed by Tukey's Multiple-Comparison Test.

A series of 10-20 ultrathin sections intercalated each 5-10 semithin section. Ultrathin sections were placed on Ni EM grids (Oxford Instruments), stained with $4 \%$ uranyl acetate and $1 \%$ lead citrate, and then observed with a JEM 1011 electron microscope (Jeol, Tokyo, Japan) equipped with a Gatan digital camera driven by Digital Micrograph software (Gatan, Pleasanton, CA). The outermost optical sections $(110 \mathrm{~nm})$ of the first and the last sections from semithin series were collected. The corresponding subsequent or previous ultrathin sections were found with an electron microscope and investigated on different magnifications $(\times 1,000$ up to $\times 40,000)$. Whole oocyte EM images were obtained by combining four to five neighboring images ( $\times 2,000$ magnification) by using Adobe Photoshop CS software.

\section{Total Lipid Content Analysis}

Analysis of total lipid content was performed according to the Nile Red-based protocol developed for bovine oocytes (23). Briefly, DO before and after IVM were fixed in $4 \%$ paraformaldehyde/1\% glutaraldehyde/0.1 M phosphate buffer $\mathrm{pH} 7.2$ for $2 \mathrm{~h}$. After three times washing in PBS, they were stained in $0.2 \mu \mathrm{g} / \mathrm{ml}$ of Nile Red diluted in PBS overnight at $4^{\circ} \mathrm{C}$. Oocytes were then incubated for $15 \mathrm{~min}$ in PBS solution with $1 \mu \mathrm{g} / \mathrm{ml}$ of Hoechst 33258 (Sigma). After being washed three times in PBS, oocytes were put on slides and mounted with Mowiol supplemented with $1 \mathrm{mg} / \mathrm{ml}$ of antifading DABCO. Fluorescence was observed using either an Axioplan Zeiss fluorescent microscope or with an Olympus FluoView 500 confocal microscope supplied with appropriate filters. Microphotographs were obtained by using camera 11.2. Color Mosaic and Spot Advanced 4.0.1 software (Diagnostic Instruments) at $\times 20$ magnification, $100 \mathrm{~ms}$ exposition was applied for all the oocytes. Images were analyzed using NIS-Elements Microscope Imaging Software (Nikon, Champigny sur Marne, France). Mean luminosity values (total luminosity/oocyte square) of immature $(n=26)$ and mature $(n=$ 89) CEO or denuded $(n=83)$ individual oocytes were compared using ANOVA followed by Tukey's Multiple-Comparison Test. Differences were considered significant at $P<0.05$.

\section{RESULTS}

\section{Maturation and Developmental Potential of CEO and DO}

CEO and DO showed a similar level of oocyte nuclear maturation after $22 \mathrm{~h}$ of IVM: $89.3 \pm 3.3$ and $88.2 \pm 3.0 \%$ of oocytes, respectively, reached metaphase II stage in our conditions. Developmental rates of CEO and DO after IVF are shown in Fig. 1. As expected, significantly less DO were cleaved at day 2 compared with CEO. Moreover, a significantly lower proportion of cleaved embryos has developed to the blastocyst from DO than from CEO at day 8 post-IVF $(20.3 \pm 4.3$ and $43.5 \pm 5.4 \%$, respectively, $P=0.015)$. The percentage of hatched blastocysts was not statistically different between two groups. However, the size of the blastocysts obtained from cleaved CEO was $20.1 \pm 8.0 \%$ larger in diameter than from their DO counterparts $(P=$ $0.022)$. 

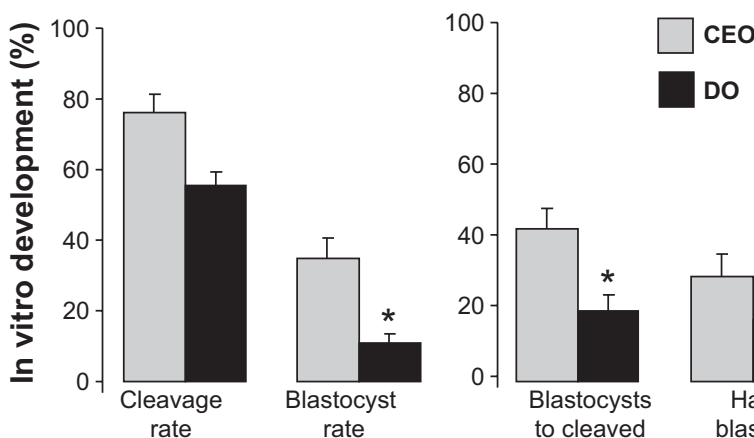

Do

Fig. 1. Comparison of the competence of cumulus-enclosed (CEO, $n=577$ ) and cumulus-denuded (DO, $n=566$ ) oocytes with in vitro embryo development after in vitro maturation (IVM) and in vitro fertilization (IVF). CEO and DO were matured separately in groups of 50 and then were fertilized in vitro together. After IVF CEO and DO were again separated, and presumptive zygotes were cultured in vitro. Cleavage rate was calculated as a ratio of a number of cleaved zygotes to a number of oocytes subjected to fertilization at day 2 after IVF; blastocyst rate was checked at day 8 , and it is relative to a number of cleaved zygotes. Data are presented as means \pm SE of four independent experiments. *The mean differs from CEO mean $(P<0.05)$.

\section{Ultrastructural Analysis of CEO and DO}

IO and in vitro matured CEO and DO were analyzed on thin and ultrathin serial sections using light and electron microscopy, respectively. IO $(n=10)$ were characterized by a clearly visible nucleus (germinal vesicle, Fig. 2, $A$ and $B$ ) up to $30 \mu \mathrm{m}$ in diameter. A large number of low electron density yolk vesicles, sometimes visibly bounded to endoplasmic reticulum (ER) membranes, were distributed throughout the ooplasm. Large dispersed gray LDs, distributed all over the ooplasm, were clearly detected by their characteristic color caused by osmium treatment (Fig. 2, $C-F$ ). Numerous mitochondria ranging from 0.5 to $1.0 \mu \mathrm{m}$ in diameter, with a dark matrix and well-developed inner membranes, were located mainly to the periphery of oocytes. They formed complexes with the vesicles and LD (Fig. 2E) located throughout the ooplasm. Cortical granules, $\sim 0.25 \mu \mathrm{m}$ in diameter, were concentrated in clusters that were often located to the periphery of the ooplasm in IO (Fig. 2F).

After IVM, only the oocytes with visible polar body were analyzed (CEO, $n=8$ and DO, $n=7$ ). Ultrastructural analysis of mature CEO is shown in Fig. 3. Polar body was observed in all mature oocytes (Fig. 3, $A$ and $B$ ). The overall aspect of all the oocytes after IVM was quite different compared with immature ones. Fewer vesicles (especially those situated at the periphery of the oocyte) were observed in mature CEO oocytes compared with IO, and also fewer complexes including LDs and mitochondria were in evidence. Morphological aspects of LDs and mitochondria were similar between IO and mature CEO. Cortical granules were organized in larger islets close to the zona pellucida (Fig. 3D). Ultrastructural analysis of the DO group revealed high similarity to CEO: the polar body and islets of cortical granules at the periphery of the ooplasm were observed in all mature oocytes (Fig. 4). Regarding white vesicle abundance, in DO an intermediate level between IO and CEO was observed. The area fraction occupied by the vesicles or by gray LDs in the ooplasm was measured in each oocyte (Fig. 5). A significant difference in vesicle area fraction was observed between DO and CEO (11.07 \pm 1.50 and $4.34 \pm$
$0.86 \%$, respectively, $P<0.05)$. A significantly higher vesicle area fraction was evidenced in IO $(18.61 \pm 1.87 \%)$ compared with $\mathrm{CEO}(P<0.001)$ and DO $(P<0.01)$. The morphological appearance of vesicles in most of CEO differed compared with IO and DO: vesicles in CEO were more translucent and seem to be "resorbed" in the ooplasm (Fig. 3, $E$ and $F$ ). Gray LD area fractions did not differ $(P>0.10)$ and averaged $0.90 \pm$ $0.17 \%$ in DO, $1.21 \pm 0.29 \%$ in CEO, and $1.76 \pm 0.39 \%$ in IO.

\section{Total Lipid Content Analysis in CEO, DO, and IO}

To compare total lipid content in the oocytes from different groups, lipid-specific fluorochrome Nile Red staining of the oocytes was quantified (198 oocytes in 3 replicates). This method was validated as a reliable technique for quantifying the total lipids in bovine and porcine oocytes $(2,23,68)$. Nile Red fluorescence revealed different distribution of lipids within the ooplasm (Fig. 6A). Relative fluorescence mean intensity (Fig. $6 B$ ) in both CEO and DO after IVM was less than in IO $(P<0.05$ and $P<0.001$, respectively), and DO had less fluorescence intensity level than CEO $(P<0.001)$.

\section{Transcriptomic Analysis of CEO and DO}

A global gene expression analysis using oligo microarray showed that from 13,609 detected oligonucleotides, only 68 appeared to be differentially expressed between metaphase II DO and CEO $(P<0.05$, ANOVA, Benjamini and Hochberg correction) with the degree of change ranging from 0.23 and 2.06. Among those 68 oligonucleotides, 34 were overexpressed in CEO and 34 were overexpressed in DO, corresponding to 26 and 30 genes upregulated in CEO and in DO, respectively (Table 2). Differentially expressed genes were subsequently classified according to their gene ontology. Several genes were involved in the regulation of transcription (DDIT3, POLR2L, MED10, LEO1) and translation (RPS10, RPS20, EIF1AX) processes. More genes overexpressed in DO were involved in RNA binding (RPS10, HEXIM2, RPS20, SNRPA1, RPUSD2, RPS17) and metal ion/cation binding (FTH1, POLR2L, RASA3), whereas genes involved in different enzyme activity (EIF1AX, NDUFA13, GYG1, ACADSB, PSMB3, GARNL1, $A S N S D 1)$ and cytoskeleton maintenance (CEP110, MYO6, CUL3) were overexpressed in CEO. In terms of gene ontology description, such as biological processes, $58.8 \%$ of differentially expressed genes were involved in the regulation of cellular metabolism, including different biosynthesis, RNA metabolic processes, proteasomal catabolism, and posttranslational protein modifications. Molecular functions significantly enriched in the list of differential genes compared with the whole list of genes of microarray $(P<0.05)$ were RNA binding and oxidoreductase/peroxidase activity. Among the genes overexpressed in CEO, many were involved in apoptosis induction and cellular component organization, whereas most of the genes upregulated in DO were assigned to different metabolic functions. We also noted an increased mRNA level $(P<0.05)$ in DO for genes involved in mitochondrial activity (ACN9, COX8A, ATPIF1), stress response (PRDX2), and in steroid and lipid synthesis (FDPS, ACLY, APOO). Besides, expression of numerous genes involved in lipid metabolism was detected in both groups of mature oocytes by microarray hybridization. Among them there were genes coding for elongation of very long chain fatty acid proteins ELOVLA and ELOVL5, fatty 
Fig. 2. Ultrastructural analysis of immature bovine oocytes. A: representative image of semithin section of immature oocyte stained with toluidine blue and captured with a confocal microscope. $B$ : one of the following ultrathin sections of the same oocyte obtained by the assembly of several electron microscopy microphotographs. Outlined rectangle surfaces are magnified in $C$ and $D . E$ and $F$ : magnification of outlined areas in $C$ and $D$, respectively. $\mathrm{GV}$, germinal vesicle; ZP, zona pellucida; V, vesicle; $\mathrm{LD}$, lipid droplet; $\mathrm{m}$, mitochondrion; $\mathrm{CG}$, cortical granules. Bars: $20 \mu \mathrm{m}(A$ and $B)$, $5 \mu \mathrm{m}(C$ and $D)$, and $1 \mu \mathrm{m}(E$ and $F)$.
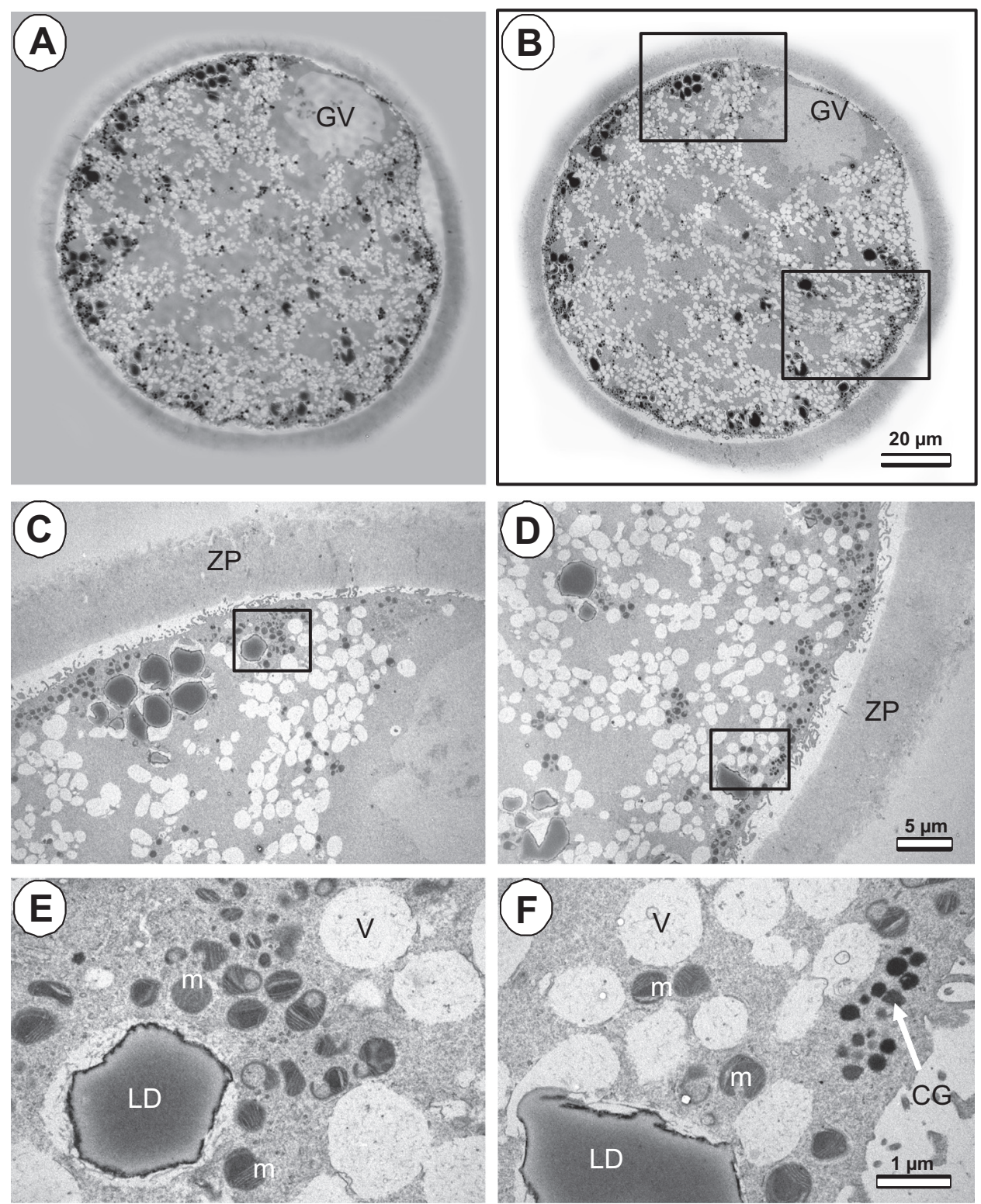

acid synthase $F A S N$, long-chain fatty acid transport proteins SLC27A1, SLC27A2, SLC27A3, and SLC27A6, several lipases including $L I P E$ (alias $H S L$ ), and also fatty acid-binding proteins $F A B P 1,3,4$, and 7 . However, their transcript level did not vary significantly between CEO and DO.

Differential expression of two genes involved in the regulation of transcription, MEDIO and LEOI (microarray CEO/DO ratio 0.66 and 1.84 , respectively), was validated by real-time RT-PCR analysis (Fig. 7) to confirm the significantly higher abundance of MEDIO and the lower level of LEOI mRNA in DO compared with CEO $(P=0.03$ and $P=0.02$, respectively). However, no statistically significant difference was found by this method for RPS17 and RPS20 genes, related to translation machinery. Expression of genes LIPE and FASN was also analyzed by real-time RT-PCR, and no significant variation in mRNA level between CEO and DO was found as expected from microarray data (data not shown). We detected LIPE and FASN transcripts in the oocytes but also in CC before and after IVM and in adipose tissue as a positive control (Fig. 8).
Here, the fragments of expected sizes were amplified by PCR from oocyte, $\mathrm{CC}$, and adipose cDNAs.

\section{Candidate Protein Abundance in $C E O$ and $D O$}

To see the differences between CEO and DO at the protein level, we quantified the abundance of the proteins either encoded by the differentially expressed genes issued from microarray analysis or those coding for candidate proteins involved in lipid metabolism. Neither LEO1 nor MED10 proteins, encoded by differentially expressed genes, could be detected by Western blot using commercial antibodies in protein extracts from groups of 50 mature DO and CEO. Relative abundance of two ribosomal proteins, corresponding to the products of RPS17 and RPS20 genes, was similar in CEO and DO (Fig. 9A). We also measured abundance and phosphorylation of one of the major kinases involved in meiosis progression, MAPK1 (alias ERK2). No significant difference in phosphorylation of MAPK1 was observed between the oocytes after 

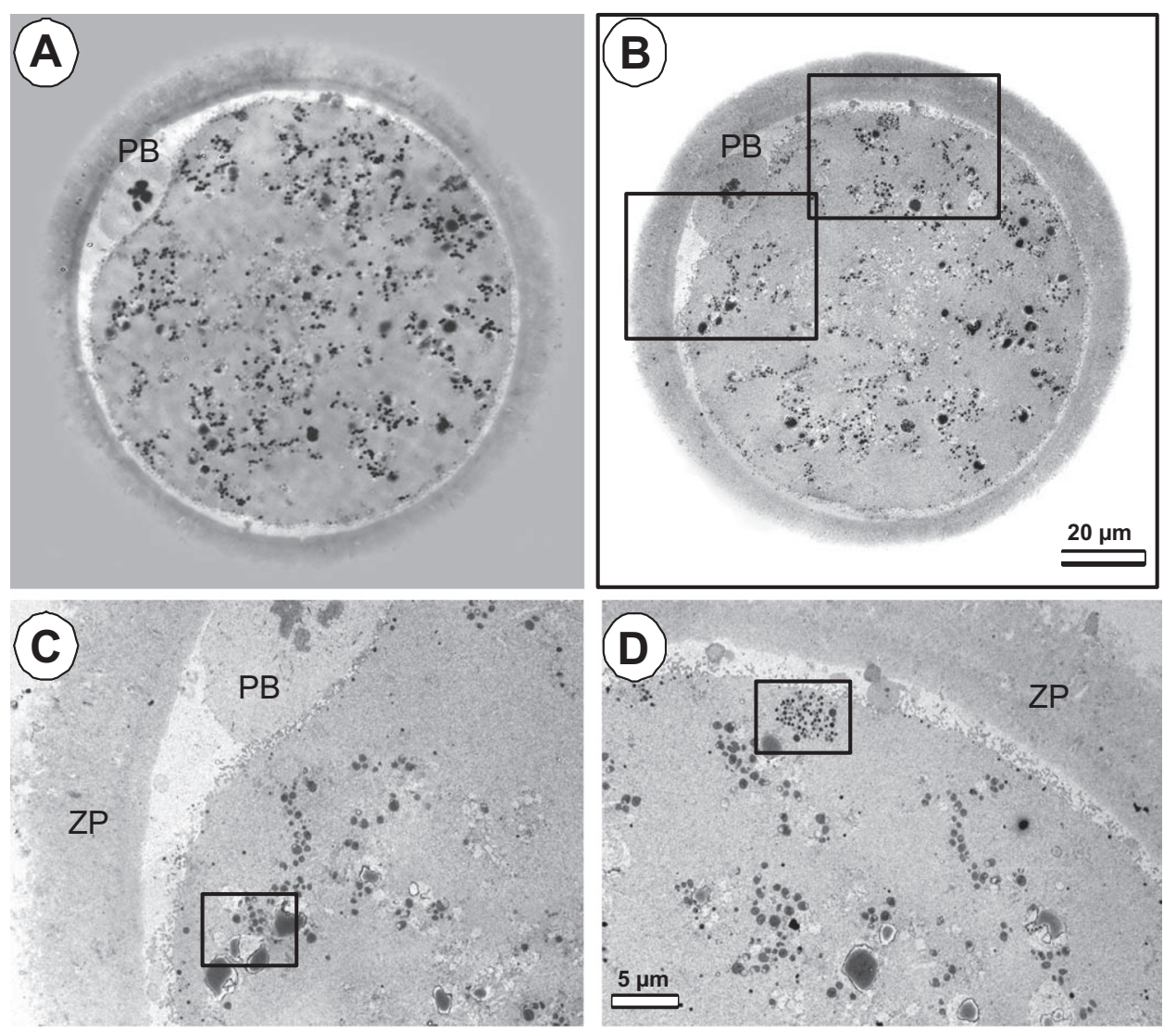

Fig. 3. Ultrastructural analysis of bovine oocyte after $22 \mathrm{~h}$ IVM with CEO. A: representative image of semithin section of mature CEO stained with toluidine blue and captured with a confocal microscope. $B$ : one of the following ultrathin sections of the same oocyte obtained by the assembly of several electron microscopy microphotographs. Outlined rectangle surfaces are magnified in $C$ and $D . E$ and $F$ : magnification of outlined areas in $C$ and $D$, respectively. $\mathrm{PB}$, polar body. Bars: $20 \mu \mathrm{m}(A$ and $B), 5 \mu \mathrm{m}(C$ and $D)$, and $1 \mu \mathrm{m}(E$ and $F)$.
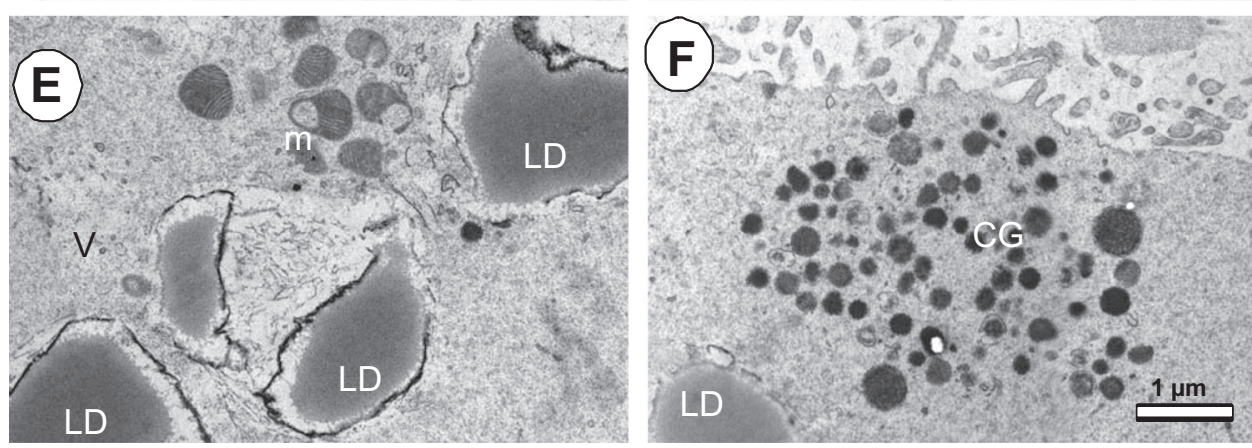

$22 \mathrm{~h}$ of IVM with or without CC (Fig. 9B). Analysis of the proteins involved in lipid metabolism revealed that the level of FAS (a protein involved in lipogenesis, encoded by the FASN gene) was significantly lower in DO than in CEO (Fig. 10). Relative abundance and Ser $^{563}$ phosphorylation of HSL (a protein involved in lipolysis, encoded by the LIPE gene) was similar between DO and CEO, and phosphorylation of HSL was not detected in IO but in both DO and CEO. The presence of FAS and HSL was also detected in CC recovered before IVM.

\section{DISCUSSION}

\section{Absence of CC During IVM Had No Effect on Oocyte Maturation Rate but Impaired In Vitro Development}

According to the present data, removal of CC before IVM affected different aspects of oocyte cytoplasmic maturation. Cytoplasmic and molecular maturation of the oocyte are poorly defined compared with nuclear meiotic maturation. Nevertheless, cytoplasmic and molecular modifications, including or- ganelle relocation, posttranscriptional modifications of mRNA, protein synthesis, and posttranslational modification, enzyme activation, etc., are essential to support embryo development $(65,66)$. Nuclear maturation rate of DO was not significantly affected compared with CEO in our conditions. Enriched maturation medium 199EM used here may counterbalance the lack of $\mathrm{CC}$ and thus prevented alteration of maturation and assured the high nuclear maturation rate of DO. Indeed, 199EM was supplemented with several metabolites such as pyruvate and cystein, which can be used by DO in the absence of CC. In cow, CC metabolize glucose to pyruvate and cystin to cystein to provide the oocyte with these energy sources, and this input promotes oocyte maturation $(24,71,73)$. Supplementation of IVM medium with gonadotropins (here, $5 \mathrm{U} / \mathrm{ml}$ of hCG and PMSG) or with EGF (10 ng/ml) is known to improve oocyte maturation and in vitro embryo development $(43,57,82)$. Insulin and IGF-I were used in IVM medium as growth- and survival-promoting factors; however, both of 
Fig. 4. Ultrastructural analysis of bovine denuded oocyte after $22 \mathrm{~h}$ IVM without cumulus cells. A: representative image of semithin section of mature DO stained with toluidine blue and captured with a confocal microscope. $B$ : one of the following ultrathin sections of the same oocyte obtained by the assembly of several electron microscopy microphotographs. Outlined rectangle surfaces are magnified in $C$ and $D . E$ and $F$ : magnification of outlined areas in $C$ and $D$, respectively. Bars: $20 \mu \mathrm{m}(A$ and $B), 5 \mu \mathrm{m}(C$ and $D)$, and $1 \mu \mathrm{m}(E$ and $F)$.
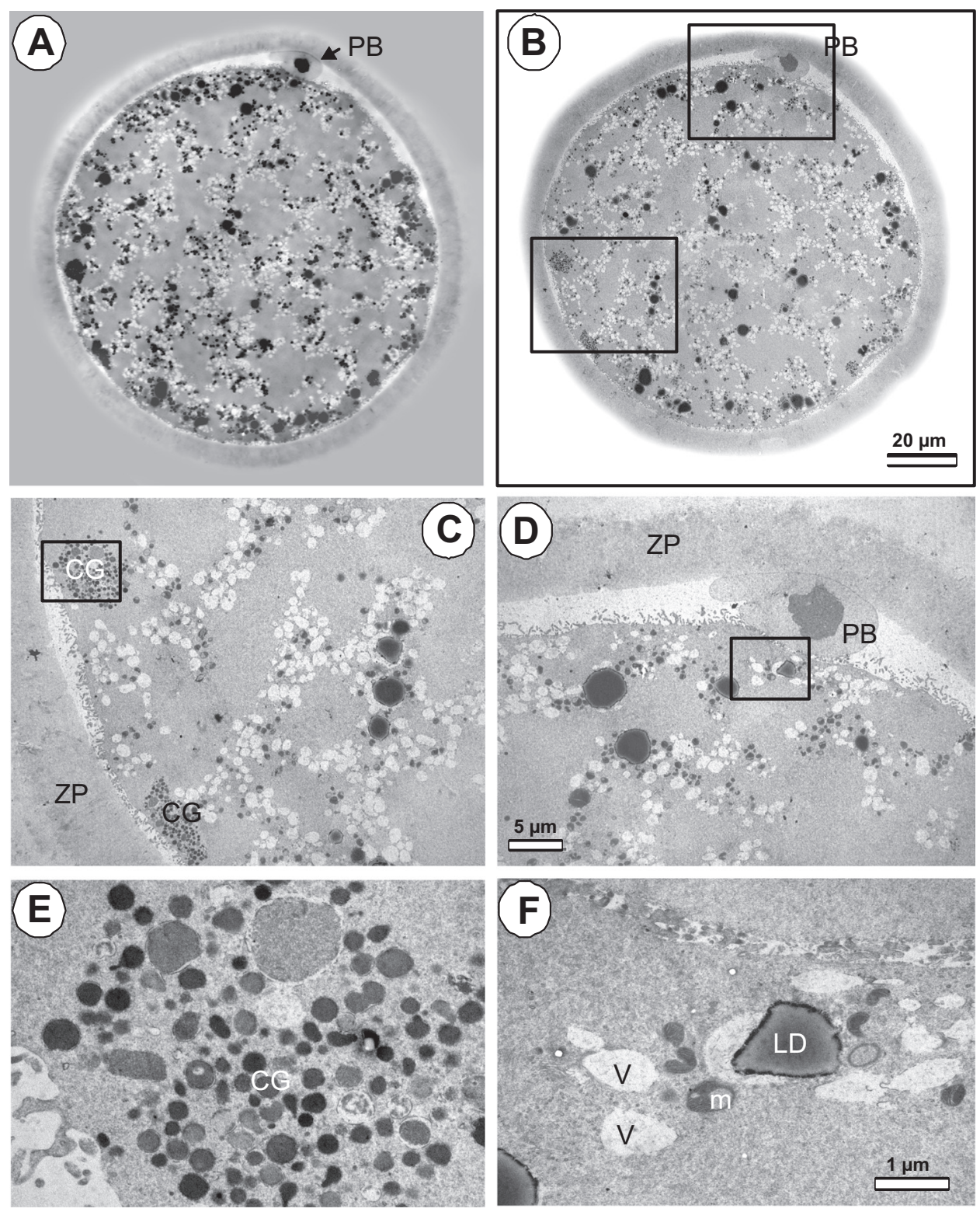

these factors are also able to induce oocyte maturation (60). Members of the insulin-signaling cascade, including glycogen synthase kinase 3B and protein kinase B (AKT), are involved in meiosis completion in bovine $(77,79)$; however, insulin had no effect on AKT phosphorylation in oocytes (54). IVM in our media supplemented with insulin and IGF-I did result in similar meiotic maturation rate in CEO and DO. Similar maturation of CEO and DO was also confirmed by an equal level of phospho-MAPK1 in these groups, since phosphoMAPK1 increased throughout IVM.

In contrast to nuclear maturation, developmental competence of DO was altered, and blastocyst rate was about one-half of that in the CEO group. This result was consistent with previous studies that reported the lower cleavage and blastocyst rates from DO in different media $(14,46)$. Interestingly, DO cocultivated with CEO during IVM were reported to have twofold higher blastocyst rate compared with DO matured alone (14). This fact indicates that CEO provides beneficial factors for developmental competence of DO. In our experiments, DO and CEO were only cocultured during IVF to ensure their fertilization, as previously shown (46). Therefore, in our experiments, poorer development of fertilized DO up to blastocyst stage was likely the result of the lack of factors from CC during IVM, which could affect oocyte maturation and embryo development. Early embryo development before embryo genome activation (EGA) is supported exclusively by oocyte transcripts and proteins $(3,62)$. In contrast, after EGA, the embryo is capable of producing its own mRNA and therefore to regulate further development. In our study, hatching rate of blastocysts developed from DO than CEO was not significantly different, consistent with the idea that oocyte components are not crucial for hatching, which is mainly assured by factors produced by the embryo itself.

\section{Absence of CC During IVM Affected the Oocyte Transcriptome}

Global gene expression analysis showed a small number of differentially expressed genes and relatively low variation level 


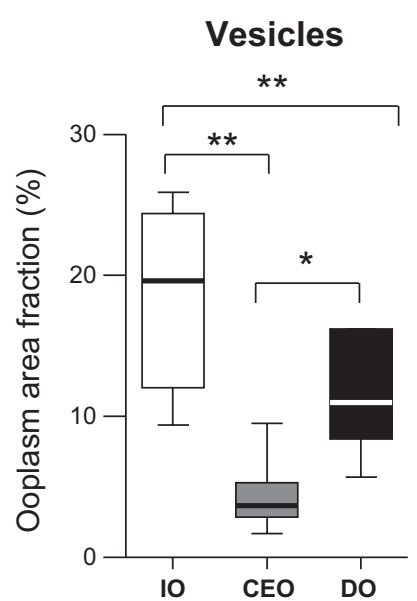

Lipid droplets

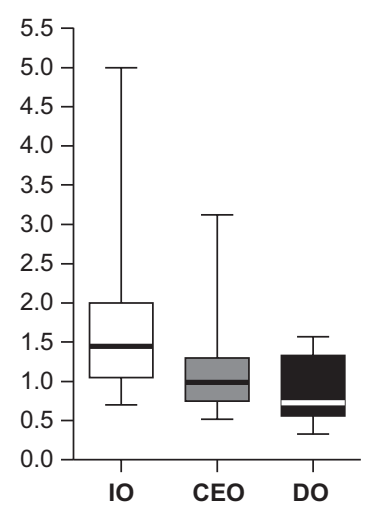

Fig. 5. Quantification of vesicle and LD abundance in the ooplasm of immature oocytes (IO) and of mature CEO and DO. The graphs represent the area fraction values of vesicles and LDs measured on midequatorial sections of individual oocytes before IVM (IO, $n=10)$ or after IVM (CEO, $n=8$ and DO, $n=7)$. Difference is significant at $P<0.05$ (*) or $P<0.01$ (**).

between mature CEO and DO. Nevertheless, among differential genes $P R D X 2$ was overexpressed in DO, which may indicate a higher response to oxidative stress, probably associated with the lack of $\mathrm{CC}$, since cumulus is known to be involved in oocyte protection against oxidative stress during maturation (9). We also evidenced significantly increased mRNA levels of FDPS, APOO, and ACLY (genes involved in steroid and lipid synthesis) in DO compared with CEO (Table 2). Although no significant difference in FASN mRNA expression was evidenced, Western blot analysis showed the significantly lower level of FAS protein in DO. In contrast, expression of genes $A C A D S B$ involved in fatty acid $\beta$-oxidation, GYG1 participating in glucose metabolism and ASNSD1 related to amino acid metabolism, was downregulated in DO (Table 2). Because CC provide energy substrates like FA and pyruvate to the oocyte, in the presence of reduced $\mathrm{CC}$, oocyte energy metabolism machinery is deviant and likely partially compensates for the lack of nutrients by utilizing the oocyte's own storage. The products of these genes might be involved in these processes. Because 199EM IVM medium contains pyruvate but not FA, it might be hypothesized that lipid synthesis is mainly affected in the oocyte and $\mathrm{CC}$ in this condition.

Several genes involved in transcription and translation also showed differences. Indeed, throughout oocyte growth, there is synthesis and accumulation of a large amount of RNA that can be translated or stored as stable transcripts for later recruitment during the last maturation steps or early embryonic development. Here, MED10, a component of the mediator complex involved in the regulation of RNA polymerase II gene and which may contribute to EGA (52), was overexpressed in DO. LEO1, an RNA polymerase II-associated protein that is involved in the regulation of transcription via histone modifications, showed the opposite regulation, i.e., overexpressed in CEO. It was also shown that LEOI was overexpressed in bovine oocytes from superovulated cows compared with nonstimulated ones (10). In addition, several ribosomal proteins (RPS10, RPS17, RPS20) were overexpressed in DO compared with CEO, and this might reflect a need for a higher level of translation to obtain enough proteins for proper oocyte maturation. However, at the protein level, neither RPS17 nor RPS20 were differentially abundant between DO and CEO groups. In fact, in the oocytes, a decoupling of transcription and translation levels was frequently observed. This is because of the absence of transcriptional activity in the oocyte during maturation, so an increase of transcript level may not reflect an increase in protein abundance. A recent transcriptomic study of bovine oocytes cultured in vitro either with or without their surrounding $\mathrm{CC}$, in medium supplemented with $12 \%$ of estrus cow serum, had shown 265 differentially expressed genes representing $\sim 2 \%$ of detected transcripts (56). The low proportion of differentially expressed genes between these two conditions in our experiment $(<0.5 \%)$ could be explained by the use of metabolically optimized enriched maturation me-
A

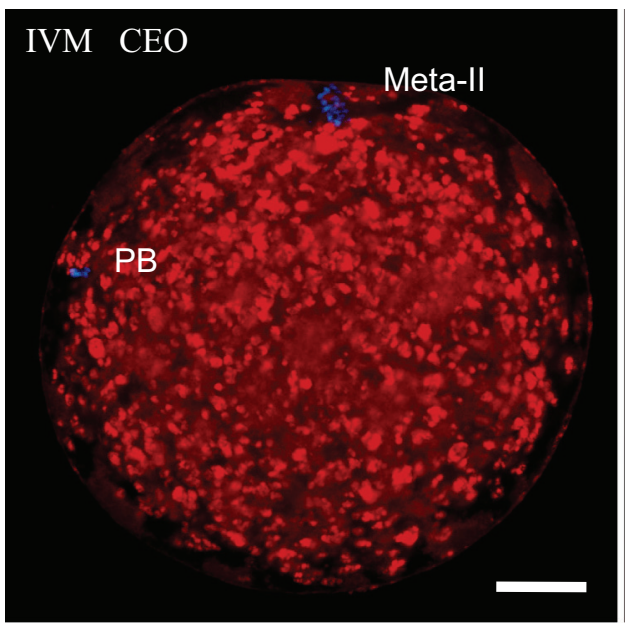

B

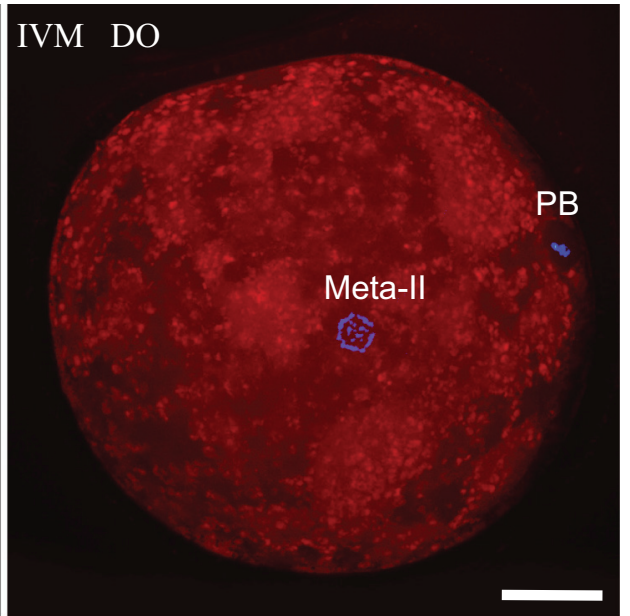

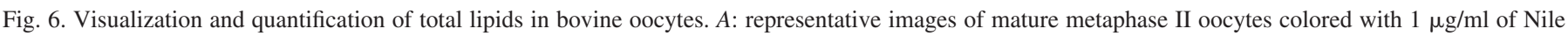

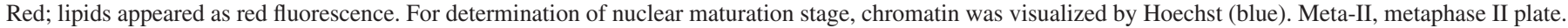

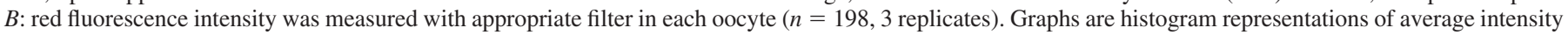
(ratio of intensity to surface) $\pm \mathrm{SE}$ of different oocyte groups. Different letters denote significant difference $(P<0.05)$. 
Table 2. List of genes differentially expressed in metaphase II oocytes after IVM cumulus-enclosed compared with denuded oocytes $(P<0.05)$

\begin{tabular}{|c|c|c|c|}
\hline Gene Symbol & Gene Description & $\begin{array}{l}\text { Ratio CEO } \\
\text { vs. DO }\end{array}$ & Known Function in Human \\
\hline EIF1AX & Eukaryotic translation initiation factor $1 \mathrm{~A}, \mathrm{X}$-linked & 2.06 & Protein biosynthesis \\
\hline GARNL1 & GTPase-activating Rap/RanGAP domain-like 1 & 2.02 & Regulation of transcription \\
\hline NDUFA13 & NADH dehydrogenase [ubiquinone] $1 \alpha$-subcomplex subunit 13 & 1.90 & NADH dehydrogenase \\
\hline SEP15 & $15-\mathrm{kDa}$ selenoprotein precursor & 1.89 & Thioredoxin peroxidase activity \\
\hline RNF166 & RING finger protein 166 & 1.84 & Zinc ion binding \\
\hline LEO1 & RNA polymerase-associated protein & 1.84 & RNA processing \\
\hline LOC532883 & Hypothetical LOC532883 & 1.83 & Unknown \\
\hline KIAA1598 & Shootin-1 & 1.78 & Kinase binding \\
\hline GTSF1 & Gametocyte-specific factor 1 & 1.74 & Metal ion binding \\
\hline $\mathrm{CNIH} 4$ & Protein cornichon homolog 4 & 1.73 & Unknown \\
\hline PSIP1 & PC4 and SFRS1-interacting protein 1 & 1.70 & Transcriptional coactivator \\
\hline MYO6 & Myosin VI & 1.55 & Actin-based motor with ATPase activity \\
\hline CUL3 & Cullin-3 & 1.53 & Ubiquitination and proteasomal degradation \\
\hline ASNSD1 & Asparagine synthetase domain-containing 1 & 1.53 & Glutamine metabolic process \\
\hline UACA & Uveal autoantigen with coiled-coil domains and ankyrin repeats & 1.51 & Regulation of stress-induced apoptosis \\
\hline OPA1 & Dynamin-like $120-\mathrm{kDa}$ protein mitochondrial precursor & 1.49 & Mitochondrial fusion and regulation of apoptosis \\
\hline ARRDC4 & Arrestin domain-containing 4 & 1.49 & Signal transduction \\
\hline CEP110 & Centrosomal protein $110 \mathrm{kDa}$ & 1.44 & Spindle formation, cytokinesis \\
\hline KCTD10 & $\mathrm{BTB} / \mathrm{POZ}$ domain-containing protein & 1.41 & Ubiquitination and proteasomal degradation \\
\hline EPRS & Bifunctional aminoacyl-tRNA synthetase & 1.38 & RNA binding \\
\hline FAM108A1 & Family with sequence similarity 108, member A1 & 1.35 & Hydrolase activity \\
\hline HNRNPD & Heterogeneous nuclear ribonucleoprotein D0 & 1.33 & RNA and DNA binding \\
\hline DENND4A & $\mathrm{C}-m y c$ promoter-binding protein & 1.32 & DNA binding \\
\hline TMEM66 & Transmembrane protein 66 precursor & 1.30 & Unknown \\
\hline ACADSB & $\begin{array}{l}\text { Short/branched-chain specific acyl-CoA dehydrogenase } \\
\text { mitochondrial precursor }\end{array}$ & 1.30 & Fatty acid metabolism \\
\hline GYG1 & Glycogenin-1 & 1.28 & Glucose metabolism \\
\hline RASA3 & Ras GTPase-activating protein 3 & 0.86 & Inhibitory regulator of AMP pathway \\
\hline KIAA2013 & Uncharacterized protein KIAA2013 precursor & 0.82 & Unknown \\
\hline APOO & Apolipoprotein O precursor & 0.79 & Lipid metabolism \\
\hline C9orf119 & Uncharacterized protein C9orf119 & 0.78 & Unknown \\
\hline ACN9 & Protein ACN9 homolog mitochondrial precursor & 0.78 & Mitochondrion activity \\
\hline POLR2L & DNA-directed RNA polymerases I, II, and III subunit & 0.78 & Regulation of transcription \\
\hline PSMB3 & Proteasome subunit $\beta$ type- 3 & 0.78 & Proteosomal protein degradation \\
\hline PSMC3 & $26 \mathrm{~S}$ protease regulatory subunit $6 \mathrm{~A}$ & 0.76 & Proteosomal protein degradation \\
\hline RPUSD2 & RNA pseudouridylate synthase domain-containing protein 2 & 0.76 & RNA binding \\
\hline DDIT3 & DNA damage-inducible transcript 3 & 0.76 & DNA-binding activity \\
\hline COX8A & Cytochrome $c$ oxidase subunit $8 \mathrm{~A}$ & 0.74 & Mitochondrion electron transport \\
\hline RPS17 & Ribosomal protein S17 & 0.74 & Regulation of translation \\
\hline SH3GL2 & Endophilin-A1 & 0.74 & Endocytosis \\
\hline FTH1 & Ferritin, heavy polypeptide 1 & 0.74 & Iron storage \\
\hline WDR13 & WD repeat-containing protein 13 & 0.74 & Unknown \\
\hline RPS10 & Ribosomal protein S10 & 0.73 & Regulation of translation \\
\hline ACLY & ATP-citrate synthase & 0.73 & Energy metabolism \\
\hline RPS10 & Ribosomal protein $\mathrm{S} 10$ & 0.73 & Regulation of translation \\
\hline TMEM42 & Transmembrane protein 42 & 0.73 & Unknown \\
\hline OOEP & Oocyte-expressed protein homolog & 0.71 & Subcortical maternal complex maintenance \\
\hline HSPA8 & Heat shock $70-\mathrm{kDa}$ protein 8 & 0.70 & Regulation of transcription \\
\hline SNRPA1 & Small nuclear ribonucleoprotein polypeptide A & 0.70 & RNA and protein binding \\
\hline HEXIM 2 & Protein HEXIM2 & 0.69 & Transcriptional regulator \\
\hline ATPIF1 & ATPase inhibitor mitochondrial precursor & 0.67 & Mitochondrion activity \\
\hline WDR13 & WD repeat-containing protein 13 & 0.67 & Protein binding \\
\hline FDPS & Farnesyl diphosphate synthase & 0.67 & Energy metabolism \\
\hline MED10 & Mediator of RNA polymerase II transcription subunit 10 & 0.66 & Regulation of transcription \\
\hline RPS20 & Similar to ribosomal protein S20 & 0.62 & Regulation of translation \\
\hline PRDX2 & Peroxiredoxin-2 & 0.60 & Stress response \\
\hline LOC493779 & $18 \mathrm{~S}$ ribosomal RNA & 0.59 & Regulation of translation \\
\hline
\end{tabular}

IVM, in vitro maturation.

dium, which may partially compensate for the absence of CC in DO by providing optimal nutrients for oocyte maturation.

Altogether, our transcriptomic data indicated that, in oocytes cultivated without their $\mathrm{CC}$, transcriptional and translational processes are modified in a way to compensate for the absence of CC.

\section{Absence of CC During IVM Affected Oocyte Cytoplasmic Maturation}

Maturation, whether in vitro or in vivo, strongly affected oocyte ultrastructure compared with the immature state (this study and Refs. 12, 30, and 31). Our study focuses and reports 


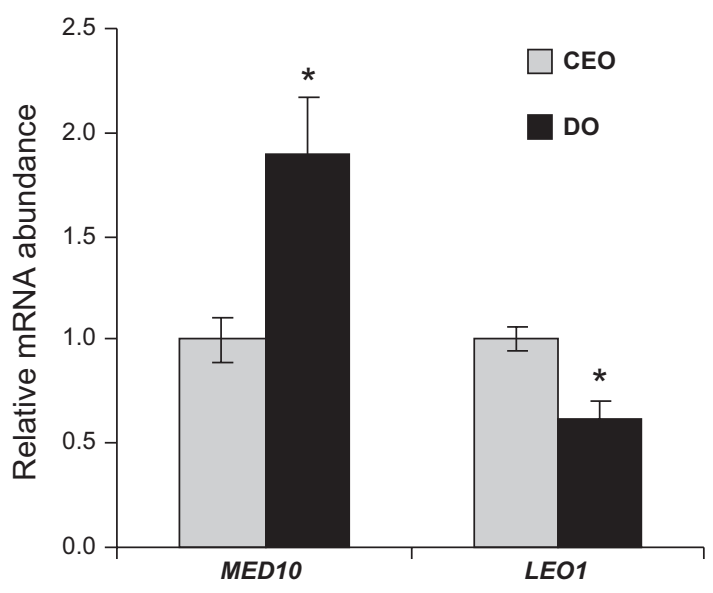

Fig. 7. Comparison of gene expression in the oocytes after IVM in the presence or absence of cumulus cells by real-time RT-PCR. Graphs are mean expression values $\pm \mathrm{SE}$ of four independent pools of PB-positive oocytes $(n=200,4$ replicates). ${ }^{*}$ The mean differs from the CEO mean $(P<0.05)$.

novel information on ooplasm modifications related to the presence or absence of CC during IVM in fatty acid-free medium. Our study clearly demonstrated that absence of CC led to aberrant cytoplasmic maturation of DO compared with CEO. Electron microscopy analysis revealed differences in ooplasm ultrastructure between DO and CEO notably in energy stock-containing structures like vesicles and LDs. For the first time, we reported that the abundance and morphology of low optical density vesicles were different between CEO and DO. Before maturation vesicles filled out the whole ooplasm, and during IVM their quantity decreased much more in CEO than in DO. Such vesicles are named "yolk" or nutritive vesicles and contain a mix of proteins, lipids, and carbohydrates of different origin (59). All these components are imported to the oocyte mainly from external fluids via diffusion, endocytosis, or via CC gap junctions and then stocked in such vesicles that are frequently associated with smooth ER. In bovine oocytes such vesicles are closely associated with mitochondria and LDs through smooth ER and form metabolic units (30). In pig oocytes, functional association of LDs with mitochondria, shown by fluorescence resonance energy transfer, strongly suggested a role for lipid metabolism during oocyte maturation (69). Most FA are stored as triacylglycerol (TAG) in neutral LDs, which are clearly visible in the ooplasm as gray spots using microscopy. The number of LDs varied significantly between species. TAG is a major lipid in mammalian oocytes, especially in porcine and bovine oocytes, which contain many more lipids compared with mice (23). We observed that LDs' content also decreased after IVM, being more consumed in DO than in CEO. Therefore, a decrease of vesicle and LD abundance during IVM means that they are consumed by the oocytes as an energy source during maturation in FA-free medium; however, their consumption rate seems to be influenced by $\mathrm{CC}$. In porcine, by comparing in vitro mature CEO and DO using fluorescent lipid and mitochondrial trackers, it was shown that CC interfered with ooplasmic LD-mitochondria distributions; moreover, LD distribution in oocytes was more sensitive to absence of $\mathrm{CC}$ than mitochondria, thus influencing oocyte morphological appearance and glutathioneATP content (11).
Therefore, the quantitative and qualitative changes of LDs and yolk vesicles between CEO and DO in our experiments could reflect functional differences notably in oocyte energy metabolism.

\section{Absence of CC During IVM Impaired Oocyte Lipid Content}

It was reported that intracellular lipids are a very important endogenous source of energy in the oocyte during maturation in different mammalian species, including bovine $(51,68)$, in addition to glucose and pyruvate uptake, which are considered key substrates to provide energy for oocyte maturation (39, 70). In fact, in our study using Nile Red, we observed a decrease of intracellular lipid contents in the oocytes after IVM compared with IO, and this was in concordance with other studies reporting lower TAG and total cholesterol content in mature oocytes than in IO $(21,37)$. Our measurements also provide evidence for significantly higher total lipid content in CEO compared with DO after IVM, suggesting differences in cumulus-related lipid metabolism between these oocyte groups. In contrast, the quantity of vesicles was higher in DO, indicating a lower consumption of their content by the oocytes lacking CC. The content of these vesicles is not clearly defined, but they likely contain phospholipids as well as carbohydrates and proteins. LDs containing mostly TAG were visible using transmission electron microscopy analysis as gray-colored and more optical dense inclusions. Intraoocyte FA composition might reflect oocyte quality in humans (48) and in cattle (37). Several studies revealed that high oocyte lipid content is associated with improved oocyte development ability $(32,69)$ and thus is consistent with higher blastocyst rate for CEO in our experiments. It was even suggested that lipid contained in the oocyte could be sufficient to support the metabolic requirements of preimplantation development as a sole energy source in porcine and bovine (69). Oocyte lipids may be used as oxidative substrates during maturation and explained the decrease in TAG and cholesterol content observed in bovine oocytes (37). This fact is consistent with a decrease in lipid content during IVM, which was observed in our study. Therefore, the lower content of total lipid observed in DO compared with CEO can reflect more intensive lipolysis and FA oxidation in DO, higher lipogenesis in CEO, or both.

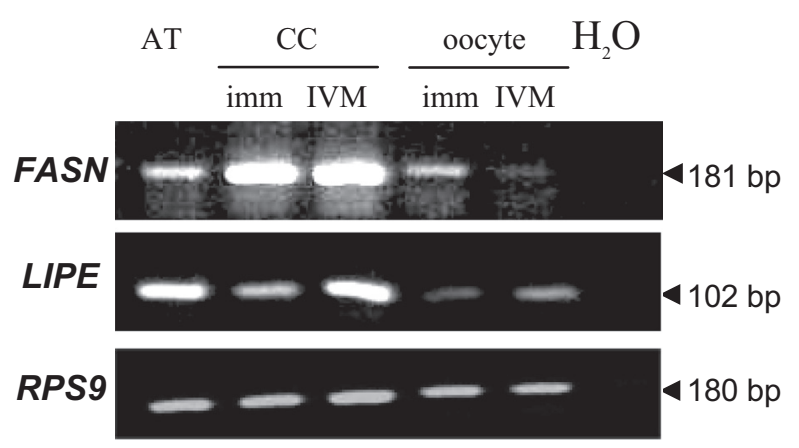

Fig. 8. Analysis of FASN and LIPE gene expression by RT-PCR in bovine cumulus cells (CC) and oocytes before (imm) and after IVM. Positive control was bovine subcutaneous adipose tissue (AT); 35 cycles of PCR were performed on converted RNA from AT and CC (1 ng equivalent) and from oocytes ( 0.1 oocyte equivalent). 
A

Fig. 9. Western blot detection and quantification of candidate proteins RPS17 and RPS20 abundance relative to $\alpha$-tubulin (TUBA, $A$ ) and mitogen-activated protein kinase (MAPK) 3/1 phosphorylation $(B)$ in CEO $(n=200$, gray bars $)$ and DO $(n=200$, black bars $) ; 50$ oocytes were loaded/ line. Specific signals were revealed using horseradish peroxidase (HRP)-conjugated secondary antibodies and quantified. Each bar represents a mean value of 4 independent replicates $\pm \mathrm{SE}$.

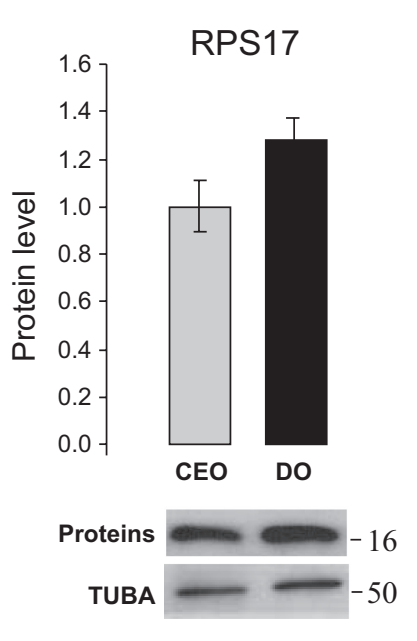

B

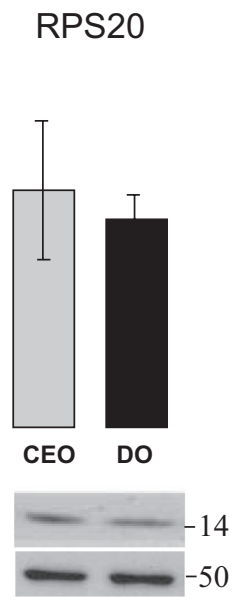

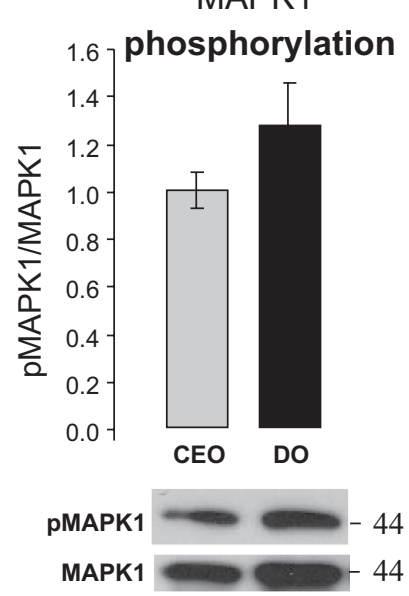

\section{Lipogenesis and Lipolysis in the Oocyte During IVM}

Here for the first time we demonstrate the presence of FAS in the oocytes and in $\mathrm{CC}$ both at the transcript and protein level. Synthesis of FA that constitutes LDs is assured by several enzymes, including FAS. FAS is encoded by FASN gene and is a multifunctional enzyme with a main purpose to catalyze the synthesis of palmitate into long-chain saturated FA. According to our data, FAS is more abundant in CC than in oocytes relative to total protein content; however, FAS is also present in the oocytes before and after IVM, which might support the idea of continuous lipogenesis in the oocytes and CC during IVM in lipid-free maturation medium. Moreover, FAS was significantly more abundant in CEO compared with $\mathrm{DO}$, suggesting either more intensive lipogenesis in oocytes maturing within $\mathrm{COC}$ or additional lipid intake from $\mathrm{CC}$ to oocyte during IVM. In fact, in cow COC, the high level of metabolic coupling between corona $\mathrm{CC}$ and the oocyte was maintained up to $9 \mathrm{~h}$ of IVM (i.e., up to oocyte metaphase I stage) and followed by a decrease to a constant low level at 13 $\mathrm{h}$ (41). In the absence of FA in maturation medium, FA could be synthesized by $\mathrm{CC}$ from the external carbohydrates present in the medium, notably glucose $(1 \mathrm{mg} / \mathrm{ml})$ and pyruvate $(0.11$ $\mathrm{mg} / \mathrm{ml}$ ), and then transported to oocytes. Moreover, IVM medium was supplemented with insulin $(5 \mu \mathrm{g} / \mathrm{ml})$, which is known to stimulate glucose uptake and activate FA synthesis while inhibiting lypolysis (58). Insulin receptor (IR) is present in both CC and oocytes (1). However, IR substrates (IRS) were different in CC and oocyte (IRS-1 and IRS-2, respectively),
A

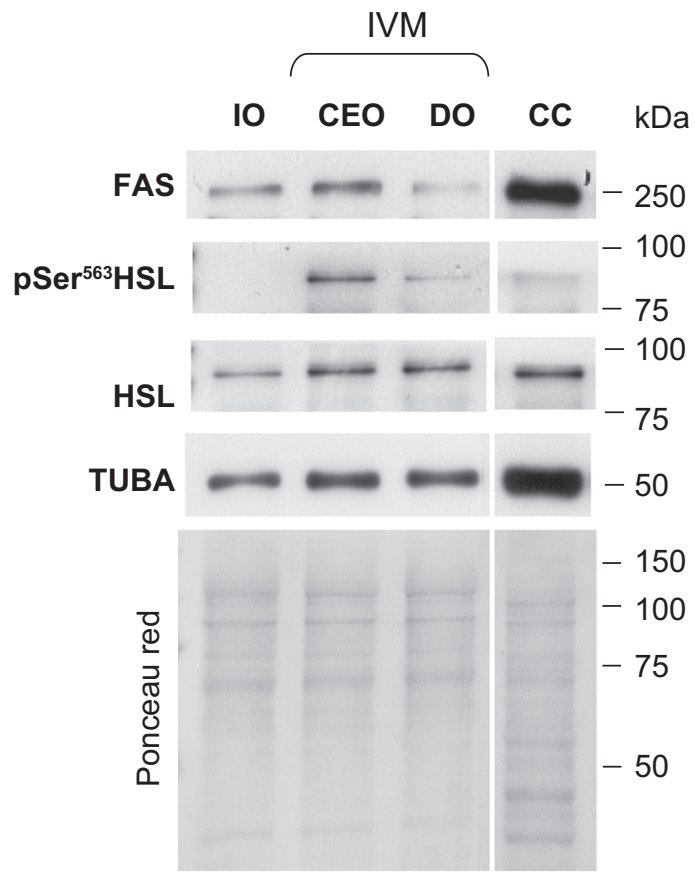

Fig. 10. Western blot immunodetection and quantification of the proteins involved in lipid metabolism in bovine oocytes. $A$ : protein extracts from 50 oocytes and $\mathrm{CC}$ were loaded/line $(\sim 4 \mu \mathrm{g})$. SDS-PAGE resolved proteins were transferred onto a nitrocellulose membrane and colored by red Ponceau (bottom), and then consecutive hybridizations with antibodies against fatty acid synthase (FAS) $\mathrm{Ser}^{563}$-phosphorylated hormone-sensitive lipase (HSL), total HSL, and TUBA were performed. Specific signals were revealed using HRP-conjugated secondary antibodies and quantified. Presented blot images were all captured from the same membrane; membrane was cut (vertical white line) to move near CC line. $B$ : quantification of relative abundance of FAS and HSL phosphorylation in the oocytes after IVM cumulus enclosed or denuded was performed on 500 oocytes in 5 replicates. Bars present mean values of 5 independent samples \pm SE. *The mean differs from CEO mean $(P<0.05)$. IVM, CC and oocytes after $22 \mathrm{~h}$ of in vitro maturation matured either $\mathrm{CEO}$ or $\mathrm{DO}$.
B

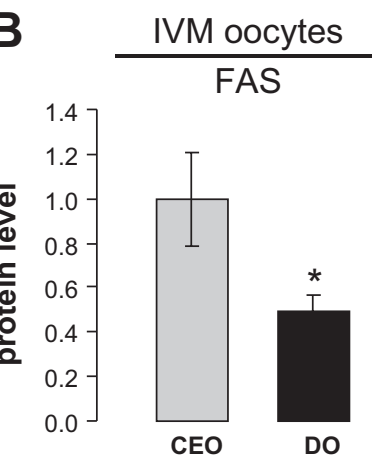

HSL

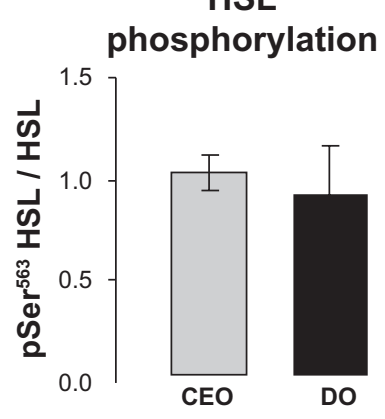


and insulin-stimulated glucose uptake occurred in CC but not in oocyte in mice (54). Different IRS had complementary roles in the control of insulin-stimulated energy metabolism: IRS-1 is more closely linked to glucose and IRS-2 to lipid metabolism (72). Therefore, insulin might act differently on FA metabolism in the oocytes enclosed or not with CC.

IGF-I was also present in our IVM 199EM medium, and in mesangial cells it was shown to induce lipid accumulation and to impair cell migration (4). Different IGF-I receptors and IGF-binding proteins were evidenced in bovine oocyte and CC (53). We could hypothesize that IGF-I had stimulated lipid accumulation in both CC and oocyte, and CEO have therefore more lipids than DO because of additive intake from CC. Alternatively, the oocyte might also synthesize FA by itself, since genes of different enzymes involved in lipogenesis are expressed in bovine oocyte according to our data and to a recent study of Van Hoeck et al. (80). However, this hypothesis needs further investigation.

In contrast to lipogenesis, lipolytic activity was well documented in bovine oocyte and thus indicates its active participation in lipid catabolism during IVM (8). In rats, immunoreactive HSL was detected in the oocytes and granulosa cells of mature follicles (42). In our study we, for the first time, detected HSL both in oocyte and CC in bovine, both at the transcript and protein level. HSL is a rate-limiting enzyme that is able to catalyze the first two steps in the breakdown of stored TAG, i.e., hydrolysis of TAG and diacylglycerol freeing the FA and monoacylglycerol, and HSL can also release cholesterol esters (40). HSL is activated by phosphorylation at several serine residues by protein kinase A, lipolytic hormones, and AMPK. Here, we detected for the first time in $\mathrm{CC}$ and in mature oocytes the HSL phosphorylated at the $\mathrm{Ser}^{563}$ regulatory site, which is thought to play a critical role in the activation of HSL, and this phosphorylation is regulated hormonally via a cAMP-dependent pathway (40). Hence, the presence of the active HSL in the oocyte during IVM indicated hydrolysis of lipid storage and release of FA for potential oxidation. Interestingly, total HSL was detected in the oocytes whatever the maturation stage; however, phosphorylation at $\mathrm{Ser}^{563}$ was detected in only mature oocytes, indicating that activation of HSL occurs during maturation. Moreover, HSL is relatively more abundant in oocytes than in CC.

In mice it was shown that fatty acid oxidation (FAO) is an important regulator of oocyte meiotic maturation (19). In addition, FAO is influenced by the level of AMPK activity (17). In bovine oocytes, meiosis resumption is associated with a decrease in AMPK activity (78), in contrast to mouse oocytes maintained in meiotic arrest by cAMP analogs in which AMPK activation stimulated meiosis resumption (16). Activation of AMPK is known to also inhibit lipid biosynthesis by phosphorylation and inactivation of key metabolic enzymes (27). AMPK activation is also associated with higher lipolysis rate in adipocytes in vitro (81). A significant decrease in nuclear meiotic maturation rate after IVM in the presence of different AMPK activators was observed in CEO but not in DO in bovine (78) and in porcine (50), species containing much higher lipids in the oocyte compared with mice. Therefore, CC might influence AMPK-dependent lipolysis in the oocyte. In mature CEO after IVM, we demonstrate herein that phosphoHSL protein was present at higher levels than in IO, and this is in accordance with a decrease in AMPK phosphorylation after
IVM (78). However, no significant variation was found in the phospho-Ser ${ }^{563}$ HSL level between CEO and DO, which means no significant influence of $\mathrm{CC}$ on the first steps of lypolysis in the oocyte.

In conclusion, CC removal before IVM in serum-free optimized medium had no effect on oocyte meiotic maturation and moderately affected oocyte transcriptome but led to suboptimal cytoplasmic maturation of DO that alters their developmental competence. Lipid storage was consumed at a higher level by DO than CEO, and this was probably because of a lack of FA provision from CC and decreased lipogenesis in the oocyte. CC therefore could influence the choice of intracytoplasmic nutritive storage available to use as an energy source for IVM in serum-free conditions.

\section{ACKNOWLEDGMENTS}

We thank Pascal Papillier for help in collection of ovaries, Christine Perreau for assistance with in vitro embryo production, Marie-Céline Deau for technical assistance with real-time PCR, Francois Moreews (SIGENAE, INRA) for annotating the bovine microarray, and Joelle Dupont for helpful discussions and providing antibodies. We also thank Dr. Philippa Kohnke for English correction.

\section{GRANTS}

Financial support for this work was obtained from Ovogenae2 (ANR-07GANI-004) and OSCILE (ANR-08-GENM-033) programs supported by grants from the French National Research Agency (ANR).

\section{DISCLOSURES}

No conflicts of interest, financial or otherwise, are declared by the authors.

\section{AUTHOR CONTRIBUTIONS}

Author contributions: S.A., R.U., S.E., L.S., L.L., and S.U. performed experiments; S.A., R.U., S.E., L.S., I.K., R.D.-T., and S.U. analyzed data; S.A., R.U., S.E., I.K., L.L., R.D.-T., and S.U. interpreted results of experiments; S.A., R.U., L.S., I.K., and S.U. prepared figures; S.A. and S.U. drafted manuscript; S.A., R.U., S.E., L.S., I.K., L.L., R.D.-T., and S.U. approved final version of manuscript; S.E., I.K., and S.U. edited and revised manuscript; R.D.-T. and S.U. conception and design of research.

\section{REFERENCES}

1. Acevedo N, Ding J, Smith GD. Insulin signaling in mouse oocytes. Biol Reprod 77: 872-879, 2007.

2. Barcelo-Fimbres M, Seidel GE Jr. Cross-validation of techniques for measuring lipid content of bovine oocytes and blastocysts. Theriogenology 75: 434-444, 2010.

3. Bashirullah A, Cooperstock RL, Lipshitz HD. Spatial and temporal control of RNA stability. Proc Natl Acad Sci USA 98: 7025-7028, 2001.

4. Berfield AK, Andress DL, Abrass CK. IGF-1-induced lipid accumulation impairs mesangial cell migration and contractile function. Kidney Int 62: 1229-1237, 2002.

5. Bettegowda A, Patel OV, Lee KB, Park KE, Salem M, Yao J, Ireland JJ, Smith GW. Identification of novel bovine cumulus cell molecular markers predictive of oocyte competence: functional and diagnostic implications. Biol Reprod 79: 301-309, 2008.

6. Buccione R, Schroeder AC, Eppig JJ. Interactions between somatic cells and germ cells throughout mammalian oogenesis. Biol Reprod 43: 543547, 1990.

7. Cecconi S, Ciccarelli C, Barberi M, Macchiarelli G, Canipari R. Granulosa cell-oocyte interactions. Eur J Obstet Gynecol Reprod Biol 115, Suppl 1: S19-S22, 2004.

8. Cetica P, Pintos L, Dalvit G, Beconi M. Activity of key enzymes involved in glucose and triglyceride catabolism during bovine oocyte maturation in vitro. Reproduction 124: 675-681, 2002.

9. Cetica PD, Pintos LN, Dalvit GC, Beconi MT. Antioxidant enzyme activity and oxidative stress in bovine oocyte in vitro maturation. IUBMB Life 51: 57-64, 2001. 
10. Chu T, Dufort I, Sirard MA. Effect of ovarian stimulation on oocyte gene expression in cattle. Theriogenology 77: 1928-1938, 2012.

11. Cui MS, Fan YP, Wu Y, Hao ZD, Liu S, Chen XJ, Zeng SM. Porcine cumulus cell influences ooplasmic mitochondria-lipid distributions, GSHATP contents and calcium release pattern after electro-activation. Theriogenology 71: 412-421, 2009.

12. de Loos F, van Maurik P, van Beneden T, Kruip TA. Structural aspects of bovine oocyte maturation in vitro. Mol Reprod Dev 31: 208 -214, 1992.

13. Delmar P, Robin S, Daudin JJ. VarMixt: efficient variance modelling for the differential analysis of replicated gene expression data. Bioinformatics 21: 502-508, 2005.

14. Dey SR, Deb GK, Ha AN, Lee JI, Bang JI, Lee KL, Kong IK. Coculturing denuded oocytes during the in vitro maturation of bovine cumulus oocyte complexes exerts a synergistic effect on embryo development. Theriogenology 77: 1064-1077, 2012.

15. Donnay I, Faerge I, Grondahl C, Verhaeghe B, Sayoud H, Ponderato N, Galli C, Lazzari G. Effect of prematuration, meiosis activating sterol and enriched maturation medium on the nuclear maturation and competence to development of calf oocytes. Theriogenology 62: 1093-1107, 2004.

16. Downs SM, Hudson ER, Hardie DG. A potential role for AMP-activated protein kinase in meiotic induction in mouse oocytes. Dev Biol 245: 200-212, 2002.

17. Downs SM, Mosey JL, Klinger J. Fatty acid oxidation and meiotic resumption in mouse oocytes. Mol Reprod Dev 76: 844-853, 2009.

18. Dudoit S, Yang YH, Callow MJ, Speed TP. Statistical methods for identifying differentially expressed genes in replicated cDNA microarray experiments. Statistica Sinica 12: 111-139, 2002.

19. Dunning KR, Cashman K, Russell DL, Thompson JG, Norman RJ, Robker RL. Beta-oxidation is essential for mouse oocyte developmental competence and early embryo development. Biol Reprod 83: 909-918, 2010.

20. Fair T, Carter F, Park S, Evans AC, Lonergan P. Global gene expression analysis during bovine oocyte in vitro maturation. Theriogenology 68, Suppl 1: S91-S97, 2007.

21. Ferguson EM, Leese HJ. Triglyceride content of bovine oocytes and early embryos. J Reprod Fertil 116: 373-378, 1999.

22. Feuerstein P, Cadoret V, Dalbies-Tran R, Guerif F, Bidault R, Royere D. Gene expression in human cumulus cells: one approach to oocyte competence. Hum Reprod 22: 3069-3077, 2007.

23. Genicot G, Leroy JL, Soom AV, Donnay I. The use of a fluorescent dye, Nile red, to evaluate the lipid content of single mammalian oocytes. Theriogenology 63: 1181-1194, 2005.

24. Geshi M, Takenouchi N, Yamauchi N, Nagai T. Effects of sodium pyruvate in nonserum maturation medium on maturation, fertilization, and subsequent development of bovine oocytes with or without cumulus cells. Biol Reprod 63: 1730-1734, 2000.

25. Gilchrist RB, Lane M, Thompson JG. Oocyte-secreted factors: regulators of cumulus cell function and oocyte quality. Hum Reprod Update 14: 159-177, 2008.

26. Gilchrist RB, Nayudu PL, Nowshari MA, Hodges JK. Meiotic competence of marmoset monkey oocytes is related to follicle size and oocytesomatic cell associations. Biol Reprod 52: 1234-1243, 1995.

27. Hardie DG, Scott JW, Pan DA, Hudson ER. Management of cellular energy by the AMP-activated protein kinase system. FEBS Lett 546: 113-120, 2003.

28. Holm P, Booth PJ, Schmidt MH, Greve T, Callesen H. High bovine blastocyst development in a static in vitro production system using SOFaa medium supplemented with sodium citrate and myo-inositol with or without serum-proteins. Theriogenology 52: 683-700, 1999.

29. Huang da W, Sherman BT, Lempicki RA. Systematic and integrative analysis of large gene lists using DAVID bioinformatics resources. Nat Protoc 4: 44-57, 2009.

30. Hyttel P, Callesen H, Greve T. Ultrastructural features of preovulatory oocyte maturation in superovulated cattle. J Reprod Fertil 76: 645-656, 1986

31. Hyttel P, Xu KP, Smith S, Greve T. Ultrastructure of in-vitro oocyte maturation in cattle. J Reprod Fertil 78: 615-625, 1986

32. Jeong WJ, Cho SJ, Lee HS, Deb GK, Lee YS, Kwon TH, Kong IK. Effect of cytoplasmic lipid content on in vitro developmental efficiency of bovine IVP embryos. Theriogenology 72: 584-589, 2009.

33. Jones GM, Cram DS, Song B, Magli MC, Gianaroli L, LachamKaplan O, Findlay JK, Jenkin G, Trounson AO. Gene expression profiling of human oocytes following in vivo or in vitro maturation. Hum Reprod 23: 1138-1144, 2008

34. Kahn BB, Alquier T, Carling D, Hardie DG. AMP-activated protein kinase: ancient energy gauge provides clues to modern understanding of metabolism. Cell Metab 1: 15-25, 2005.

35. Katz-Jaffe MG, McCallie BR, Preis KA, Filipovits J, Gardner DK. Transcriptome analysis of in vivo and in vitro matured bovine MII oocytes. Theriogenology 71: 939-946, 2009.

36. Kidder GM, Vanderhyden BC. Bidirectional communication between oocytes and follicle cells: ensuring oocyte developmental competence. Can J Physiol Pharmacol 88: 399-413, 2010.

37. Kim JY, Kinoshita M, Ohnishi M, Fukui Y. Lipid and fatty acid analysis of fresh and frozen-thawed immature and in vitro matured bovine oocytes. Reproduction 122: 131-138, 2001.

38. Kimura N, Hoshino Y, Totsukawa K, Sato E. Cellular and molecular events during oocyte maturation in mammals: molecules of cumulusoocyte complex matrix and signalling pathways regulating meiotic progression. Soc Reprod Fertil Suppl 63: 327-342, 2007.

39. Krisher RL, Bavister BD. Enhanced glycolysis after maturation of bovine oocytes in vitro is associated with increased developmental competence. Mol Reprod Dev 53: 19-26, 1999.

40. Lampidonis AD, Rogdakis E, Voutsinas GE, Stravopodis DJ. The resurgence of Hormone-Sensitive Lipase (HSL) in mammalian lipolysis. Gene 477: 1-11, 2011

41. Laurincik J, Kroslak P, Hyttel P, Pivko J, Sirotkin AV. Bovine cumulus expansion and corona-oocyte disconnection during culture in vitro. Reprod Nutr Dev 32: 151-161, 1992.

42. Lobo MV, Huerta L, Arenas MI, Busto R, Lasuncion MA, MartinHidalgo A. Hormone-sensitive lipase expression and IHC localization in the rat ovary, oviduct, and uterus. J Histochem Cytochem 57: 51-60, 2009.

43. Lonergan P, Carolan C, Van Langendonckt A, Donnay I, Khatir H, Mermillod P. Role of epidermal growth factor in bovine oocyte maturation and preimplantation embryo development in vitro. Biol Reprod 54: 1420-1429, 1996.

44. Lonergan P, Gutierrez-Adan A, Rizos D, Pintado B, de la Fuente J, Boland MP. Relative messenger RNA abundance in bovine oocytes collected in vitro or in vivo before and $20 \mathrm{hr}$ after the preovulatory luteinizing hormone surge. Mol Reprod Dev 66: 297-305, 2003.

45. Luciano AM, Franciosi F, Modina SC, Lodde V. Gap junction-mediated communications regulate chromatin remodeling during bovine oocyte growth and differentiation through cAMP-dependent mechanism(s). Biol Reprod 85: 1252-1259, 2011.

46. Luciano AM, Lodde V, Beretta MS, Colleoni S, Lauria A, Modina S. Developmental capability of denuded bovine oocyte in a co-culture system with intact cumulus-oocyte complexes: role of cumulus cells, cyclic adenosine $3^{\prime}, 5^{\prime}$-monophosphate, and glutathione. Mol Reprod Dev 71: 389-397, 2005.

47. Mamo S, Carter F, Lonergan P, Leal CL, Al Naib A, McGettigan P, Mehta JP, Evans AC, Fair T. Sequential analysis of global gene expression profiles in immature and in vitro matured bovine oocytes: potential molecular markers of oocyte maturation (Abstract). BMC Genomics 12: 151, 2011.

48. Matorras R, Ruiz JI, Mendoza R, Ruiz N, Sanjurjo P, RodriguezEscudero FJ. Fatty acid composition of fertilization-failed human oocytes. Hum Reprod 13: 2227-2230, 1998.

49. Matzuk MM, Burns KH, Viveiros MM, Eppig JJ. Intercellular communication in the mammalian ovary: oocytes carry the conversation. Science 296: 2178-2180, 2002.

50. Mayes MA, Laforest MF, Guillemette C, Gilchrist RB, Richard FJ. Adenosine 5'-monophosphate kinase-activated protein kinase (PRKA) activators delay meiotic resumption in porcine oocytes. Biol Reprod 76: 589-597, 2007.

51. McEvoy TG, Coull GD, Broadbent PJ, Hutchinson JS, Speake BK. Fatty acid composition of lipids in immature cattle, pig and sheep oocytes with intact zona pellucida. J Reprod Fertil 118: 163-170, 2000.

52. Myers LC, Kornberg RD. Mediator of transcriptional regulation. Апnи Rev Biochem 69: 729-749, 2000.

53. Nuttinck F, Charpigny G, Mermillod P, Loosfelt H, Meduri G, Freret S, Grimard B, Heyman Y. Expression of components of the insulin-like growth factor system and gonadotropin receptors in bovine cumulusoocyte complexes during oocyte maturation. Domest Anim Endocrinol 27: 179-195, 2004. 
54. Purcell SH, Chi MM, Lanzendorf S, Moley KH. Insulin-stimulated glucose uptake occurs in specialized cells within the cumulus oocyte complex. Endocrinology 153: 2444-2454, 2012.

55. Purcell SH, Moley KH. Glucose transporters in gametes and preimplantation embryos. Trends Endocrinol Metab 20: 483-489, 2009.

56. Regassa A, Rings F, Hoelker M, Cinar U, Tholen E, Looft C, Schellander $\mathbf{K}$, Tesfaye $\mathbf{D}$. Transcriptome dynamics and molecular cross-talk between bovine oocyte and its companion cumulus cells (Abstract). BMC Genomics 12: 57, 2011.

57. Salhab M, Tosca L, Cabau C, Papillier P, Perreau C, Dupont J, Mermillod P, Uzbekova S. Kinetics of gene expression and signaling in bovine cumulus cells throughout IVM in different mediums in relation to oocyte developmental competence, cumulus apoptosis and progesterone secretion. Theriogenology 75: 90-104, 2011.

58. Saltiel AR, Kahn CR. Insulin signalling and the regulation of glucose and lipid metabolism. Nature 414: 799-806, 2001.

59. Schjeide OA, Galey F, Grellert EA, RISL, De Vellis J, Mead JF. Macromolecules in oocyte maturation. Biol Reprod 2, Suppl 2: 14-43, 1970.

60. Schmitt A, Nebreda AR. Signalling pathways in oocyte meiotic maturation. J Cell Sci 115: 2457-2459, 2002.

61. Schneider CA, Rasband WS, Eliceiri KW. NIH Image to ImageJ: 25 years of image analysis. Nat Methods 9: 671-675, 2000.

62. Seydoux G. Mechanisms of translational control in early development. Curr Opin Genet Dev 6: 555-561, 1996.

63. Sirard MA. Follicle environment and quality of in vitro matured oocytes. J Assist Reprod Genet 28: 483-488, 2011.

64. Sirard MA. Resumption of meiosis: mechanism involved in meiotic progression and its relation with developmental competence. Theriogenology 55: 1241-1254, 2001.

65. Sirard MA, Richard F, Blondin P, Robert C. Contribution of the oocyte to embryo quality. Theriogenology 65: 126-136, 2006.

66. Smith GD. In vitro maturation of oocytes. Curr Womens Health Rep 1: 143-151, 2001.

67. Steeves TE, Gardner DK. Metabolism of glucose, pyruvate, and glutamine during the maturation of oocytes derived from pre-pubertal and adult cows. Mol Reprod Dev 54: 92-101, 1999.

68. Sturmey RG, O’Toole PJ, Leese HJ. Fluorescence resonance energy transfer analysis of mitochondrial:lipid association in the porcine oocyte. Reproduction 132: 829-837, 2006.

69. Sturmey RG, Reis A, Leese HJ, McEvoy TG. Role of fatty acids in energy provision during oocyte maturation and early embryo development. Reprod Domest Anim 44, Suppl 3: 50-58, 2009.

70. Sutton-McDowall ML, Gilchrist RB, Thompson JG. The pivotal role of glucose metabolism in determining oocyte developmental competence. Reproduction 139: 685-695, 2010.
71. Tanghe S, Van Soom A, Nauwynck H, Coryn M, de Kruif A. Minireview: Functions of the cumulus oophorus during oocyte maturation, ovulation, and fertilization. Mol Reprod Dev 61: 414-424, 2002.

72. Taniguchi CM, Ueki K, Kahn R. Complementary roles of IRS-1 and IRS-2 in the hepatic regulation of metabolism. J Clin Invest 115: 718 -727, 2005.

73. Tatemoto H, Sakurai N, Muto N. Protection of porcine oocytes against apoptotic cell death caused by oxidative stress during In vitro maturation: role of cumulus cells. Biol Reprod 63: 805-810, 2000.

74. Telford NA, Watson AJ, Schultz GA. Transition from maternal to embryonic control in early mammalian development: a comparison of several species. Mol Reprod Dev 26: 90-100, 1990.

75. Thelie A, Papillier P, Pennetier S, Perreau C, Traverso JM, Uzbekova S, Mermillod P, Joly C, Humblot P, Dalbies-Tran R. Differential regulation of abundance and deadenylation of maternal transcripts during bovine oocyte maturation in vitro and in vivo (Abstract). BMC Dev Biol 7: 125, 2007.

76. Thelie A, Papillier P, Perreau C, Uzbekova S, Hennequet-Antier C, Dalbies-Tran R. Regulation of bovine oocyte-specific transcripts during in vitro oocyte maturation and after maternal-embryonic transition analyzed using a transcriptomic approach. Mol Reprod Dev 76: 773-782, 2009.

77. Tomek W, Smiljakovic T. Activation of Akt (protein kinase B) stimulates metaphase I to metaphase II transition in bovine oocytes. Reproduction 130: 423-430, 2005 .

78. Tosca L, Uzbekova S, Chabrolle C, Dupont J. Possible role of 5'AMPactivated protein kinase in the metformin-mediated arrest of bovine oocytes at the germinal vesicle stage during in vitro maturation. Biol Reprod 77: 452-465, 2007.

79. Uzbekova S, Salhab M, Perreau C, Mermillod P, Dupont J. Glycogen synthase kinase $3 \mathrm{~B}$ in bovine oocytes and granulosa cells: possible involvement in meiosis during in vitro maturation. Reproduction 138: 235-246, 2009.

80. Van Hoeck V, Leroy JL, Arias-Alvarez M, Rizos D, Gutierrez-Adan A, Schnorbusch K, Bols PE, Leese HJ, Sturmey RG. Oocyte developmental failure in response to elevated non-esterified fatty acid concentrations: mechanistic insights. Reproduction 145: 33-44, 2013.

81. Yin W, Mu J, Birnbaum MJ. Role of AMP-activated protein kinase in cyclic AMP-dependent lipolysis In 3T3-L1 adipocytes. J Biol Chem 278: 43074-43080, 2003.

82. Younis AI, Brackett BG, Fayrer-Hosken RA. Influence of serum and hormones on bovine oocyte maturation and fertilization in vitro. Gamete Res 23: 189-201, 1989. 